\title{
Sex Differences in Nucleus Accumbens Transcriptome Profiles Associated with Susceptibility versus Resilience to Subchronic Variable Stress
}

\author{
Georgia E. Hodes, ${ }^{1}$ Madeline L. Pfau, ${ }^{1}$ Immanuel Purushothaman, ${ }^{1}$ H. Francisca Ahn, ${ }^{1}$ Sam A. Golden, ${ }^{1}$ \\ DDaniel J. Christoffel, ${ }^{1}$ Jane Magida, ${ }^{1}$ Anna Brancato, ${ }^{1,6}$ Aki Takahashi, ${ }^{1,2}$ @Meghan E. Flanigan, ${ }^{1}$ @Caroline Ménard, \\ Hossein Aleyasin, ${ }^{1}$ Ja Wook Koo, ${ }^{1}$ 'Zachary S. Lorsch, ${ }^{1}$ ' Jian Feng, ${ }^{1}$ Mitra Heshmati, ${ }^{1}$ Minghui Wang, ${ }^{3}$ \\ Gustavo Turecki, ${ }^{4}$ Rachel Neve, ${ }^{5}$ Bin Zhang, ${ }^{3}$ Li Shen, ${ }^{1}$ Eric J. Nestler, ${ }^{1}$ and Scott J. Russo ${ }^{1}$ \\ ${ }^{1}$ Fishberg Department of Neuroscience and Friedman Brain Institute, Icahn School of Medicine at Mount Sinai, New York, New York 10029, ${ }^{2}$ Laboratory of \\ Behavioral Neuroendocrinology, University of Tsukuba, Tsukuba, Ibaraki 305-8577, Japan, ${ }^{3}$ Genetics and Genomic Sciences, Icahn School of Medicine at \\ Mount Sinai, New York, New York 10029, ${ }^{4}$ McGill Group for Suicide Studies, Douglas Mental Health University Institute, Department of Psychiatry, \\ Montreal, Quebec H4H 1R3, Canada, ${ }^{5}$ Department of Brain and Cognitive Sciences, Massachusetts Institute of Technology, Cambridge, Massachusetts \\ 02139, and ${ }^{6}$ Department of Science for Health Promotion and Mother and Child Care, University of Palermo, 90127 Palermo, Italy
}

Depression and anxiety disorders are more prevalent in females, but the majority of research in animal models, the first step in finding new treatments, has focused predominantly on males. Here we report that exposure to subchronic variable stress (SCVS) induces depressionassociated behaviors in female mice, whereas males are resilient as they do not develop these behavioral abnormalities. In concert with these different behavioral responses, transcriptional analysis of nucleus accumbens (NAc), a major brain reward region, by use of RNA sequencing (RNA-seq) revealed markedly different patterns of stress regulation of gene expression between the sexes. Among the genes displaying sex differences was DNA methyltransferase $3 \mathrm{a}($ Dnmt3a), which shows a greater induction in females after SCVS. Interestingly, Dnmt3a expression levels were increased in the NAc of depressed humans, an effect seen in both males and females. Local overexpression of Dnmt3a in NAc rendered male mice more susceptible to SCVS, whereas Dnmt3a knock-out in this region rendered females more resilient, directly implicating this gene in stress responses. Associated with this enhanced resilience of female mice upon NAc knock-out of Dnmt3a was a partial shift of the NAc female transcriptome toward the male pattern after SCVS. These data indicate that males and females undergo different patterns of transcriptional regulation in response to stress and that a DNA methyltransferase in NAc contributes to sex differences in stress vulnerability.

Key words: behavior; depression; epigenetics; nucleus accumbens; sex differences; stress

\section{Significance Statement}

Women have a higher incidence of depression than men. However, preclinical models, the first step in developing new diagnostics and therapeutics, have been performed mainly on male subjects. Using a stress-based animal model of depression that causes behavioral effects in females but not males, we demonstrate a sex-specific transcriptional profile in brain reward circuitry. This transcriptional profile can be altered by removal of an epigenetic mechanism, which normally suppresses DNA transcription, creating a hybrid male/ female transcriptional pattern. Removal of this epigenetic mechanism also induces behavioral resilience to stress in females. These findings shed new light onto molecular factors controlling sex differences in stress response.

\section{Introduction}

Men and women manifest different symptoms and coping responses to episodes of depression (Martin et al., 2013); and based on current diagnostic schemes, women have twice the incidence of depression and anxiety disorders (Kessler et al., 1994). Despite this sex-based skew in the occurrence of stress-related illness, basic research has lagged in including female animals in stress studies (Beery and Zucker, 2011). When females are included, 
research has demonstrated numerous sex differences in stress responses between males and females, including different cellular responses to stress (Bangasser and Valentino, 2012; Chow et al., 2013; Howerton et al., 2014), different brain circuits involved in stress responses (Bangasser and Shors, 2008; Shansky et al., 2010; Kelly et al., 2014; Stevens et al., 2014), sex-specific effects of stress on synaptic and neural plasticity (Shors et al., 2004; Autry et al., 2009; Carvalho-Netto et al., 2011; Chow et al., 2013; Galea et al., 2013; Farrell et al., 2015; McEwen et al., 2015), and myriad differences in the cognitive and emotional behavioral effects of stress exposure (Bowman et al., 2001, 2003; Monteggia et al., 2007; Dalla et al., 2008, 2011; LaPlant et al., 2009). Together, these studies raise the possibility that transcriptional regulation differs between the sexes and that such differences may contribute to stress vulnerability and resilience.

There is growing evidence for sex differences in the nucleus accumbens (NAc), a brain area important for reward and stress processing (Russo and Nestler, 2013). Males and females show different susceptibility to addiction, and this is thought to relate to differences in the brain's reward and stress circuitry (Anker and Carroll, 2011; Becker et al., 2012). Females exhibit structural differences in NAc neural plasticity at baseline (Wissman et al., 2012) and after cocaine exposure (Wissman et al., 2011), and they are far more sensitive to the addictive properties of cocaine (Lynch and Carroll, 2000; Lynch et al., 2000; Russo et al., 2003). Less is known about the molecular basis of sex differences in stress susceptibility; and to date, most studies examining sex differences in molecular correlates of addiction or stress behavior in NAc have used a candidate gene approach (LaPlant et al., 2009; Sato et al., 2011; Rappeneau et al., 2015). It is not currently known how males and females compare with respect to the molecular cascades in the NAc that are altered by stress exposure.

Epigenetic mechanisms have been implicated in sex differences in gene expression and sexual differentiation of the brain (Tsai et al., 2009; Ghahramani et al., 2014; Morrison et al., 2014; Nugent et al., 2015; Shen et al., 2015). Sexual differentiation in the brain is triggered by a gonadal hormone surge (Rhees et al., 1990; MacLean et al., 1997), which drives defeminization and subsequent masculinization. The process of masculinizing the brain involves methylation of the estrogen receptor $\alpha$ (Kurian et al., 2010; Schwarz et al., 2010) along with sex differences in histone acetylation (Murray et al., 2009; Matsuda et al., 2011). These early epigenetic sex differences result in sex-specific sexual behaviors in adulthood (Matsuda et al., 2011; Nugent et al., 2015) and have been implicated in vulnerability to mental disorders in humans (Kim et al., 2015). Epigenetic regulation is also implicated in vulnerability to repeated social defeat stress during adulthood (Tsankova et al., 2006; Elliott et al., 2010; LaPlant et al., 2010; Golden et al., 2013), but these preclinical studies have been limited to males.

Using the subchronic variable stress (SCVS) model, which consists of $6 \mathrm{~d}$ of alternating stressors, we explored sex differences in stress responses on a battery of depression- and anxiety-like behaviors and on transcriptional regulation in the NAc with RNA sequencing (RNA-seq). We hypothesized that sex differences in the transcriptional profile of the NAc are associated with sex differences in stress susceptibility. Our findings implicate an important role of the DNA methyltransferase, Dnmt3a, in medi-

Correspondence should be addressed to Dr. Scott J. Russo, Icahn School of Medicine at Mount Sinai, Department of Neuroscience, 1425 Madison Avenue, Room 10-20A, New York, NY 10029. E-mail: scott.russo@mssm.edu. DOI:10.1523/JNEUROSCI.1392-15.2015

Copyright $\odot 2015$ the authors $\quad 0270-6474 / 15 / 3516363-15 \$ 15.00 / 0$ ating female-male differences in stress susceptibility and in transcriptional responses to stress.

\section{Materials and Methods}

Animals. C57BL/6J female and male mice (The Jackson Laboratory) at 8-12 weeks of age were used for all experiments, except Dnmt3a knock-out studies. For Dnmt3a conditional deletion, Dnmt $3 \mathrm{a}^{2 \mathrm{lox} / 2 \mathrm{lox}}$ mice were bred at the Icahn School of Medicine from a line originally generated in the laboratory of En Li at Novartis Institutes of Biomedical Research (Dodge et al., 2005). They were backcrossed with 129Jae mice for 8 generations to generate a common genetic background. Dnmt3a ${ }^{2 \text { lox/2lox }}$ mice were between 8 and 20 weeks old at the time of behavioral experiments. One week before the onset of each experiment, mice were group housed and maintained on a $12 \mathrm{~h}$ light/dark cycle with ad libitum access to food and water, except when explicitly stated for behavioral testing. All mice that underwent behavioral testing were single housed following the splash test, the first portion of the behavioral test battery. Mouse procedures were performed in accordance with the Institutional Animal Care and Use Committee guidelines of the Icahn School of Medicine at Mt. Sinai.

Subchronic variable stress. SCVS was performed as described previously (LaPlant et al., 2009), which consists of three different stressors over $6 \mathrm{~d}$ (Fig. $1 a)$. Stressors alternated during the $6 \mathrm{~d}$ to prevent stress habituation. Stressors were administered in the following order: 100 random mild foot shocks at $0.45 \mathrm{~mA}$ for $1 \mathrm{~h}$ ( 10 mice to a chamber), a tail suspension stress for $1 \mathrm{~h}$ and restraint stress, placed inside a $50 \mathrm{ml}$ falcon tube, for $1 \mathrm{~h}$ within the home cage. The three stressors were then repeated for the next $3 \mathrm{~d}$ in the same order. In some experiments, we used an abbreviated (3 d) subthreshold variable stress (STVS) to assess stress susceptibility.

Behavioral assessments: splash test. Testing was based on a published protocol (Isingrini et al., 2010). The test was performed under red light $(230 \mathrm{~V}, 15 \mathrm{~W})$. Mice were habituated to the room for $1 \mathrm{~h}$ before testing. Mice were sprayed on the back with a $10 \%$ sucrose solution 3 times. Mice were then placed into an empty housing cage, and behavior for $5 \mathrm{~min}$ was recorded via videotape. The total amount of time grooming over the 5 min period was recorded and hand scored by an observer blind to experimental conditions. Mice were immediately single housed after the test.

Novelty suppressed feeding. Testing was adapted from a published protocol (Santarelli et al., 2003). Mice were food restricted overnight before testing. On the day of testing, mice habituated to the testing room for $1 \mathrm{~h}$. Under red light conditions, mice were then placed into a plastic box $50 \times$ $50 \times 20 \mathrm{~cm}$ with bedding. A single pellet of food was placed in the center of the box. Mice were placed in the corner of the box, and the latency to eat was scored up to $10 \mathrm{~min}$ during testing. Mice were then immediately transferred to their home cage in standard lighting conditions, and the latency to eat was recorded.

Sucrose consumption test. Testing was conducted according to previously published protocols (Krishnan et al., 2007; Vialou et al., 2010). Immediately after the splash test, mice were separated and individually housed. They were given 2 bottles filled with water for a $24 \mathrm{~h}$ habituation period. The following day, immediately after novelty suppressed feeding (NSF) testing, one of the two $50 \mathrm{ml}$ bottles was replaced with a $1 \%$ sucrose bottle for $24 \mathrm{~h}$. The 2 bottles were then weighed, and position was switched for an additional $24 \mathrm{~h}$. The total duration of the test was $48 \mathrm{~h}$. Sucrose was calculated by determining the percentage of total sucrose consumption divided by total liquid consumption (sucrose + water).

Forced swim test (FST). The FST was conducted according to previously published protocols (LaPlant et al., 2010). At $24 \mathrm{~h}$ after the NSF test, animals were placed in the test room for an hour before behavioral testing. Mice were tested in a $4 \mathrm{~L}$ Pyrex glass beaker, containing $2 \mathrm{~L}$ of water at $25+1^{\circ} \mathrm{C}$ for $6 \mathrm{~min}$. Behavior was videotaped and hand scored using a $5 \mathrm{~s}$ sampling method for percentage time spent immobile by an observer blind to experimental conditions.

Elevated plus maze (EPM). Mice were acclimated to the testing facility for $1 \mathrm{~h}$ before testing. Animals were placed in the EPM under red light conditions for $5 \mathrm{~min}$. Each arm of the maze measured $12 \times 50 \mathrm{~cm}$. The black Plexiglas cross-shaped maze consisted of two open arms with no walls and two closed arms (40 cm high walls) and was on a pedestal $1 \mathrm{~m}$ above floor level. Behavior was tracked using an automated system (Noldus Ethovision; Noldus Interactive Technologies). Behavior was mea- 
a
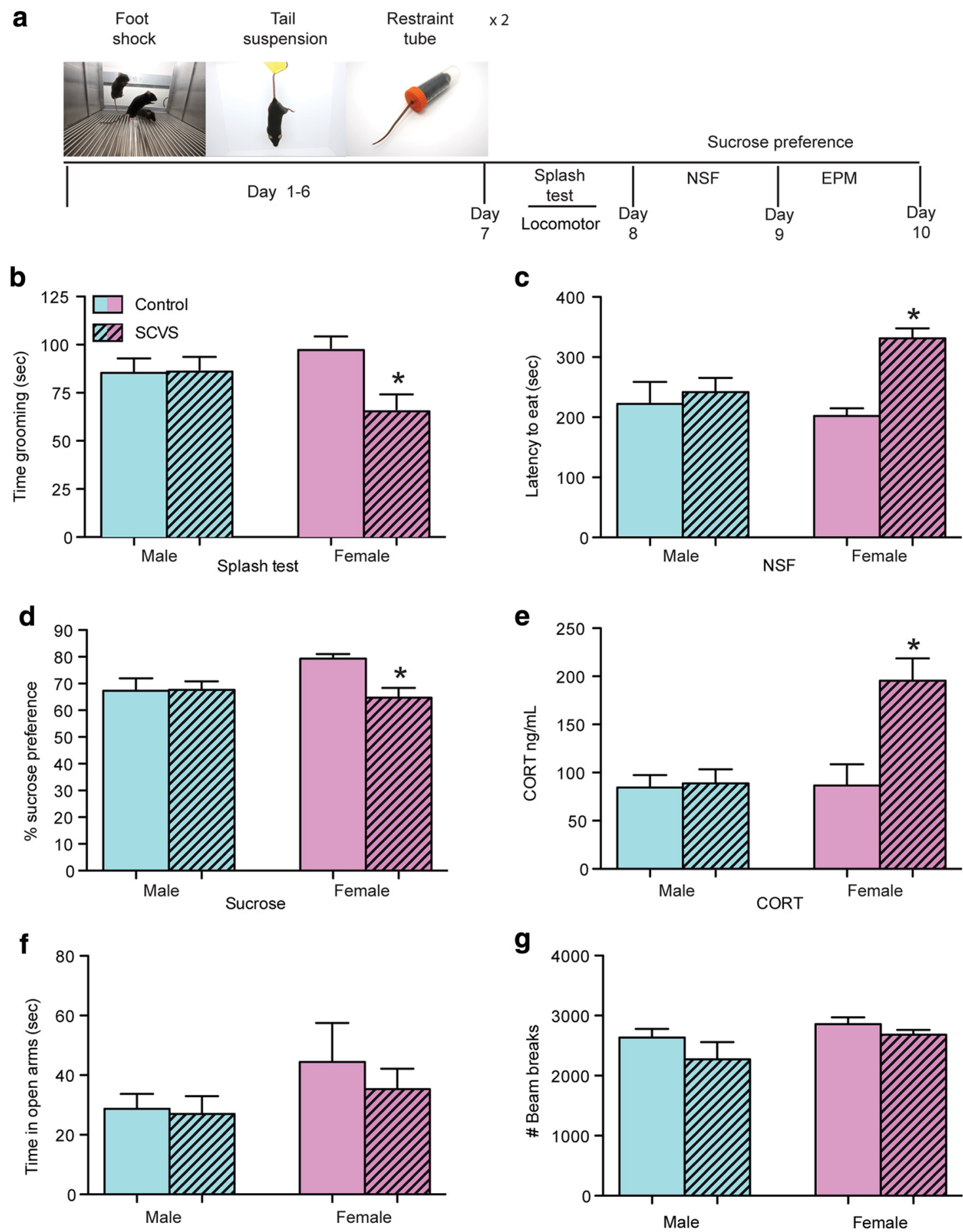

Elevated Plus Maze

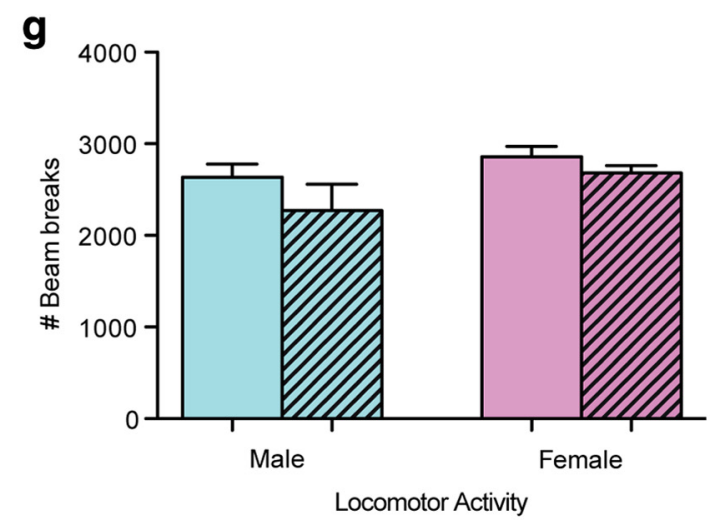

Figure 1. SCVS induces stress susceptibility in female but not male mice. $\boldsymbol{a}$, Schematic of SCVS and behavioral testing. $\boldsymbol{b}$, SCVS exposed female mice spent less time grooming in the splash test than males or unstressed females. $\boldsymbol{c}$, Female mice that underwent SCVS demonstrated longer latencies to eat in a novel environment than males or unstressed females. $\boldsymbol{d}$, Female mice exposed to SCVS displayed reduced sucrose preference. $\boldsymbol{e}$, Circulating levels of corticosterone (CORT) were increased by SCVS in females $24 \mathrm{~h}$ after the last stress exposure. Males showed none of these deficits $(\boldsymbol{b}-\boldsymbol{e}) . \boldsymbol{f}$, There were no sex differences or effects of stress on time spent in the open arms of the EPM. $\boldsymbol{g}$, There were no sex differences or effects of stress on locomotor activity. ${ }^{*}$ Significant interaction between sex and stress as analyzed by two-way ANOVA followed by Bonferroni post hoc analysis ( $n=8-10 /$ sex/stress).

sured as total time in combined open arms and total time in combined closed arms.

Locomotor activity. Locomotor activity ( $n=8$ per group) was measured in a separate cohort of animals exposed to SCVS. One day after the last stressor, mice were acclimated to the testing room $1 \mathrm{~h}$ and tested under red light. They were placed into clear testing chambers $(44.45 \mathrm{~cm}$ length $\times 17.78 \mathrm{~cm}$ width $\times 25.4 \mathrm{~cm}$ height), and the number of photobeam breaks on the $x$ and $y$ planes were measured for 30 min using an automated system (PAS, San Diego Instruments).

Surgery. Herpes simplex virus (HSV)-mediated Dnmt3a overexpression. Male and female C57BL/6J mice ( $n=9$ or 10 per group splash test, NSF sucrose, FST; cohort 1 ; cohort 2, $n=8$ per group EPM/locomotor 
activity were anesthetized with a mixture of ketamine $(100 \mathrm{mg} / \mathrm{kg})$ and xylazine $(10 \mathrm{mg} / \mathrm{kg})$ and positioned in a small-animal stereotaxic instrument (David Kopf Instruments) with the skull surface exposed. Thirtythree-gauge syringe needles (Hamilton) were used to bilaterally infuse $0.5 \mu \mathrm{l}$ of HSV $\left(1.5 \times 10^{12}\right.$ infectious units $\left./ \mathrm{ml}\right)$ expressing a control green fluorescent protein (GFP) or Dnmt3a in to NAc (bregma coordinates: anteroposterior, $+1.5 \mathrm{~mm}$; mediolateral, $+1.6 \mathrm{~mm}$; dorsoventral, -4.4 $\mathrm{mm})$ at a rate of $0.1 \mathrm{ml} / \mathrm{min}$.

Adeno-associated virus (AAV) cre-mediated Dnmt3a knock-out. Male and female $D n m t 3 \mathrm{a}^{2 \mathrm{lox} / 2 \mathrm{lox}}$ mice $(n=12$ mice per group for RNA-seq and 8-11 mice per group for splash test, NSF, sucrose, FST; cohort 1; cohort 2, $n=5-7$ for EPM/locomotor activity) were anesthetized with a ketamine/xylazine mixture described above, and surgery was performed as described for HSV. Animals were bilaterally infused with $0.5 \mu \mathrm{l}$ of AAV $\left(1.5 \times 10^{12}\right.$ infectious units/ml) expressing a control GFP or Cre/GFP in to NAc (coordinates listed above). Viral vectors have been tested and validated in vivo and in vitro (LaPlant et al., 2010).

Corticosterone ELISA. Submandibular vein bleeds (Golde et al., 2005) were taken $24 \mathrm{~h}$ after the last stressor, and serum was collected as previously described (Hodes et al., 2014).

Corticosterone (CORT) levels were measured in serum with a commercially available sandwich ELISA kit (ImmunoDiagnostic Systems) according to the manufacturers' instructions. Intra-assay variability for the corticosterone assay ranged from $3.8 \%$ to $6.6 \%$; interassay variability ranged from $7.5 \%$ to $8.6 \%$; mean assay sensitivity was $0.55 \mathrm{ng} / \mathrm{ml}$.

Estrous cycle. All females were swabbed to detect stage of the estrous cycle following death as previously described (Hodes et al., 2009, 2010), and slides of cells smears were stained with $1 \%$ toluidine blue. Cycle stage was determined by visual inspection and recorded.

Tissue collection and RNA extraction: mouse. NAc samples were collected and processed as described previously (Golden et al., 2013). Bilateral 14-gauge NAc dorsal striatum punches were collected on ice after rapid decapitation and then immediately placed on dry ice and stored at $-80^{\circ} \mathrm{C}$ until use. RNA was isolated using homogenization in Trizol (Invitrogen) followed by chloroform layer separation. The clear RNA layer was then processed (RNAeasy MicroKit, QIAGEN) and analyzed with NanoDrop (Thermo Scientific). A total of $500 \mathrm{ng}$ of RNA was then reverse transcribed to cDNA (qScript Kit, VWR).

Tissue collection and RNA extraction: human. Whole-tissue NAc resections were collected by the Quebec Suicide Brain Bank at the Douglas Hospital Research center under an approval of the Douglas Hospital Research Center's Research Ethics Committee as previously published (Golden et al., 2013). Next of kin permission was obtained, and brain tissue was collected from cases at the local medical examiners offices $(n=$ 44). Subjects with known history of neurological disorders or head injury were excluded, and blood toxicology screened out any subject using illicit drugs or psychotropic medications. Clinical records and collateral information from telephone interviews with a primary caregiver were obtained for each case. Three or four mental health professionals performed an extensive review of the clinical information and made independent diagnoses followed by a consensus diagnosis using the Diagnostic and Statistical Manual of Mental Disorders IV criteria. The three groups (control, medicated depressed, and nonmedicated depressed) were matched as closely as possible for race, gender, age, $\mathrm{pH}$, postmortem interval, and RNA integrity number (RIN) and demographics have been previously published (Golden et al., 2013). Acceptable RIN values were within the range 6.1-9.5. NAc was dissected and immediately placed in a mixture of dry ice and isopentane (1:1 vol:vol). The frozen tissue was then pulverized on dry ice and stored at $-80^{\circ} \mathrm{C}$. To determine $\mathrm{pH}$ and RIN tissue weighing $\sim 150 \mathrm{mg}$ was punched from the cerebellum, homogenized in $5 \mathrm{ml}$ of $\mathrm{ddH}_{2} \mathrm{O}$ (pH adjusted to 7.00), and centrifuged for $3 \mathrm{~min}$ at $8000 \times \mathrm{g}$ and $4^{\circ} \mathrm{C}$. The $\mathrm{pH}$ of the supernatant was measured in duplicate (Thermo Electron). RIN determination was performed by isolating total RNA using Trizol (Invitrogen) followed by analysis with an Agilent 2100 Bioanalyzer.

$q R T-P C R$. cDNA was diluted to $500 \mu \mathrm{l}$, and $3 \mu \mathrm{l}$ was used for each reaction. The reaction mixture consisted of Perfecta SYBR Green (VWR) $(5 \mu \mathrm{l})$, forward and reverse primers $(0.5 \mu \mathrm{l}$ each), water $(1 \mu \mathrm{l})$, and the cDNA template. Samples were then heated to $95^{\circ} \mathrm{C}$ for $2 \mathrm{~min}$ followed by
40 cycles of $95^{\circ} \mathrm{C}$ for $15 \mathrm{~s}, 60^{\circ} \mathrm{C}$ for $33 \mathrm{~s}$, and $72^{\circ} \mathrm{C}$ for $33 \mathrm{~s}$. Analysis was done using the $\Delta \Delta \mathrm{C}(\mathrm{t})$ method. Dnmt3a primer for mouse was previously published (LaPlant et al., 2010) and specific to isoform 1. All samples were normalized to GAPDH. Primer pairs are available upon request (Integrated DNA Technologies).

RNA-seq and differential analysis. Library construction was performed following a previously published protocol (Feng et al., 2014). Bilateral 14 gauge NAc dorsal striatum punches were collected on ice and stored as described above. RNA was purified with RNeasy Micro columns, and Bioanalyzer confirmed that the RNA integrity numbers were $>8.0$. Total RNA $(4 \mu \mathrm{g})$ was used for mRNA library construction following instructions of Illumina mRNA sample prep kit (catalog \#RS-100-0801). Libraries were created from pooled mRNA samples $(n=4$ mice/library and run in independent biological replicates of 3 libraries per sex/stress). Each stage of the estrous cycle was equally represented within all female libraries. All libraries were sequenced on an Illumina HiSeq 2000 machine at the Icahn School of Medicine at Mt. Sinai. Short reads were aligned to the Ensembl Mus musculus NCBIM37 version 67 reference genome using TopHat2 (Kim et al., 2013). Quality assessment revealed an $80 \%-90 \%$ mapping rate, with $\sim 10 \%$ of reads mapping to mitochondrial RNA and $<1 \%$ aligning to ribosomal RNA. Individual gene counts for each sample were obtained using the HTSeq python package (Anders et al., 2015). Before differential analysis, only genes with $>5$ reads in at least $80 \%$ of samples in any one of the experimental conditions were included. Counts were converted to precision weighted $\log 2$ counts per million using the voom transformation, a function of the Bioconductor R package limma (Law et al., 2014; Ritchie et al., 2015). The limma package was used to fit a $2 \times 2$ factorial design interaction model with stress and sex as main factors to determine the effect of stress in males and in females separately. The same design was used to investigate the effect of Dnmt3a knock-out in stressed males and stressed females with sex and genotype as main factors. An uncorrected $p$ value $<0.05$ and a fold change threshold of 1.3 were used to determine differential expressions between genes.

Quantitative gene overlap. Genes differentially expressed between conditions were divided into upregulated and downregulated groups. Using custom software in R, lists were combined pairwise, generating a total of 120 unique comparisons. For each comparison, the gene IDs in each list were extracted, and the quantitative overlap between the two lists was determined. Subsequently, a Fisher's exact test was used to statistically analyze the overlap based on the number of genes in common, the size of each gene list, and the total number of background genes, examining whether the observed gene overlap was significantly $(p<0.05)$ larger than expected by chance. For all comparisons, the number of background genes was kept constant at 18,724 reflecting the total number of candidate genes analyzed in the differential expression analysis. Additionally, the fold change between observed gene overlap and expected gene overlap was recorded.

Pathway analysis. Pathway and network analysis were performed on differentially regulated genes using Ingenuity Pathway Analysis (QIAGEN; www.qiagen.com/ingenuity).

Statistical analysis. Differences between two groups were compared using unpaired $t$ tests (two-tailed). Comparisons of multiple factors or repeated measures were analyzed by bivariate ANOVAs with a Bonferroni post test for post hoc analysis. All statistical analyses were performed using Graph Pad Prism 5.0 software (Graphpad). Statistical significance was set a $p<0.05$. Grubbs outlier test was performed and samples that varied $>2$ SDs from the mean were removed.

\section{Results}

\section{Female but not male mice are susceptible to SCVS}

We showed previously that $6 \mathrm{~d}$ of SCVS increased passive coping behavior in female but not male mice in the FST (LaPlant et al., 2009), a test commonly used to screen for antidepressant drug efficacy. Here we expanded on these findings by putting male and female mice through a behavioral test battery of anxiety, locomotor, and depression associated behaviors following SCVS (Fig. $1 a)$. The initial test battery included the splash test, NSF, sucrose preference, and EPM. Locomotor activity was measured subse- 


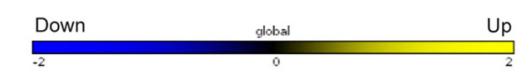

a

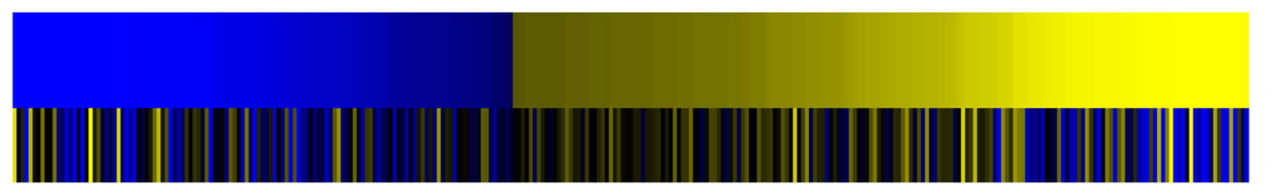

Female

stress vs. no stress

Male

Male
stress vs. no stress

b

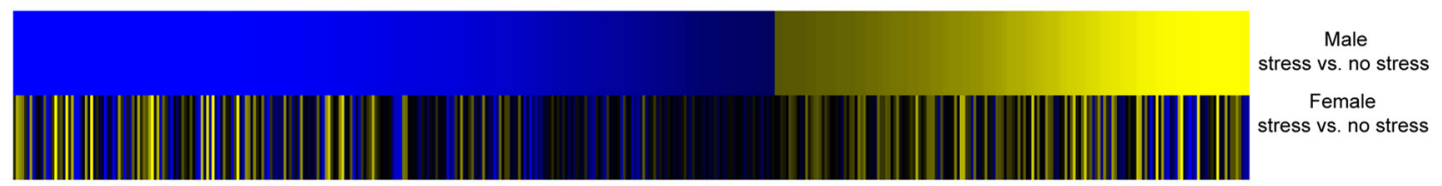

C Up regulated

d Down regulated
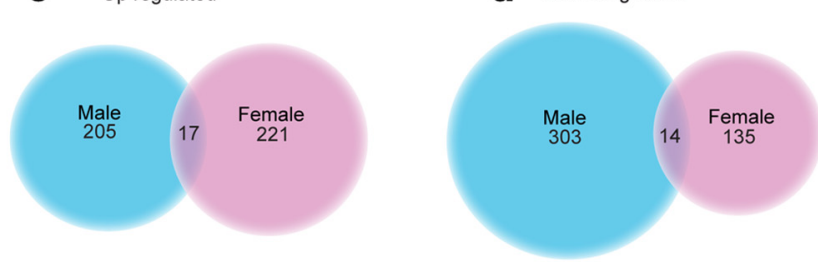

e

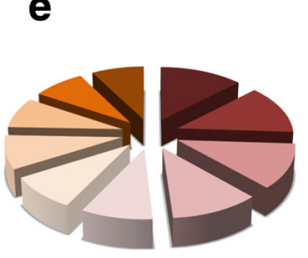

$$
\begin{aligned}
& \text { Nervous system } \\
& \text { development and fun } \\
& \text { Nucleic acid } \\
& \text { metabolism } \\
& \text { Cardiovascular } \\
& \text { DNA replication } \\
& \text { Cell growth/ } \\
& \text { proliferation } \\
& \text { Cell function } \\
& \text { Cell cycle } \\
& \text { Cell to cell } \\
& \text { signaling } \\
& \text { Molecular transport } \\
& \text { Cancer }
\end{aligned}
$$
development and function

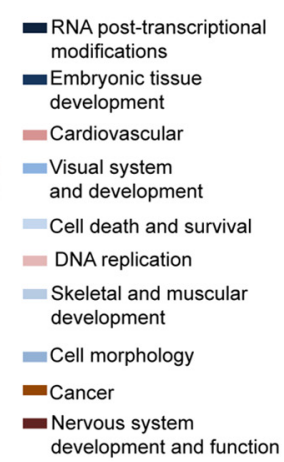

Figure 2. Male and female mice express different transcriptional responses in NAc after SCVS. $\boldsymbol{a}$, Heatmap of genes differentially regulated by SCVS in females compared with the same genes in males. $\boldsymbol{b}$, Heatmap of genes differentially regulated by SCVS in males compared with females. $\boldsymbol{c}$, Venn diagrams of total number of significantly upregulated genes in stressed males and females. $\boldsymbol{d}$, Venn diagram of total number of downregulated genes in stressed males and females. $\boldsymbol{e}$, Representation of the top 10 gene ontology networks regulated by SCVS in males and females. Libraries were created from pooled mRNA samples ( $n=4$ mice/library and run in independent biological replicates of 3 libraries per sex/stress).

quently in a separate cohort of mice to confirm that behavioral effects in the above mentioned tests were not due to sex- or stressrelated differences in physical activity. For the splash test, animals were sprayed with a sticky $10 \%$ sucrose solution, and subsequent grooming behavior was examined; stressed mice groomed less than unstressed mice (Surget et al., 2008). Mice that underwent NSF were food deprived overnight and then placed in a novel environment where latency to eat is examined; stressed animals have a longer latency to eat. This test has been implicated in both anxiety and depression-associated behavior (Santarelli et al., 2003). Sucrose preference was examined as a measure of anhedonia, a key symptom of depression. The EPM was used as a measure of exploratory behavior related to anxiety (File, 2001). Female mice that underwent SCVS exhibited a series of depression-like behaviors, including decreased grooming in the splash test (Fig. 1b), indicated by a significant interaction between stress and $\operatorname{sex}\left(F_{(1,34)}=5.48, p=0.02\right)$. Female mice that underwent SCVS also displayed increased latency to eat in the novelty suppressed feeding test (Fig. 1c) as indicated by a significant interaction between stress and $\operatorname{sex}\left(F_{(1,30)}=4.96, p=0.03\right)$. SCVS decreased sucrose preference in females (Fig. $1 d$ ) as indicated by a significant interaction between stress and $\operatorname{sex}\left(F_{(1,32)}=\right.$ $4.22, p=0.05)$. Furthermore, SCVS increased levels of corti- costerone only in female mice (Fig. 1e) as demonstrated by a significant interaction $\left(F_{(1,33)}=7.97, p=0.008\right)$. Male mice subjected to identical SCVS exhibited none of these abnormalities in depression-like behavior or stress hormone levels $(p>$ $0.05)$. Neither sex displayed altered anxiety-like behavior as indicated by the EPM (Fig. $1 f ; p>0.05$ ). Additionally, there were no differences in locomotor activity between male and female mice or between stressed and unstressed mice (Fig. 1g; $p>0.05)$.

\section{SCVS induces different transcriptional profiles in male and female mice}

To discover unbiased biological correlates of sex differences in susceptibility versus resilience to SCVS, we used RNA-seq to measure all polyA-containing transcripts in NAc of control and stressed animals. Males and females were exposed to SCVS and NAc tissue was sampled $24 \mathrm{~h}$ after the last stressor. Heatmaps of significantly regulated genes were constructed from the global transcriptome analysis (Fig. 2a,b). Overall, 17\% more genes in the NAc were regulated by stress compared to same sex controls for males than for females, indicating a more active transcriptional process in males exposed to SCVS. The majority of genes $(\sim 60 \%)$ were upregulated in females exposed to SCVS com- 
Table 1. Top 20 genes downregulated or upregulated by SCVS compared with same sex controls for females and males

\begin{tabular}{|c|c|c|c|c|c|}
\hline Gene name & Fold change & $p$ value & Gene name & Fold change & $p$ value \\
\hline Female down & & & Male down & & \\
\hline Eif4e3 & -2.577990489 & 0.005651417 & Gm14398 & -3.383830645 & 0.005096422 \\
\hline Pax9 & -2.434715154 & 0.006331814 & BC107364 & -2.915796547 & 0.002979085 \\
\hline Gm13833 & -2.403345361 & 0.004448435 & $\operatorname{Cdh} 3$ & -2.913895317 & 0.028056667 \\
\hline C030005K15Rik & -2.215372988 & 0.025409394 & snoU105B & -2.885983623 & 0.001437604 \\
\hline Gm9043 & -2.180304737 & 0.034446421 & СТ030723.1 & -2.678330083 & 0.005915608 \\
\hline Pawr & -2.144101779 & 0.016350813 & En1 & -2.677377799 & 0.014496827 \\
\hline 4930404N11Rik & -2.134035973 & 0.007781197 & Gm10566 & -2.632350505 & 0.004650241 \\
\hline Gm5546 & -2.103048946 & 0.007694025 & Gm16675 & -2.632350505 & 0.009281196 \\
\hline Gm13634 & -2.099684564 & 0.010428945 & Rab44 & -2.628757266 & 0.04532264 \\
\hline$A C 140327.1$ & -2.08862837 & 0.029437298 & Gm572 & -2.545880965 & 0.013394635 \\
\hline 1700020C07Rik & -2.080896077 & 0.015118536 & Apon & -2.504881626 & 0.017774897 \\
\hline Gm16161 & -2.049360086 & 0.027645093 & Ptprq & -2.472708755 & 0.016148697 \\
\hline Gm11942 & -2.016659894 & 0.007862275 & Glt28d2 & -2.465520661 & 0.017331428 \\
\hline Slfn3 & -2.016567555 & 0.026341926 & $\operatorname{lgfn} 1$ & -2.425890994 & 0.021956617 \\
\hline Hmgn2-ps1 & -2.014701945 & 0.044670803 & Gm12532 & -2.424408816 & 0.009856372 \\
\hline $\mathrm{Npb}$ & -1.974874424 & 0.036187813 & Aplnr & -2.403880885 & 0.035825609 \\
\hline Gm14225 & -1.942222579 & 0.038747955 & $\| 17 b$ & -2.402915763 & 0.008693424 \\
\hline AC026231.1 & -1.893124397 & 0.025550695 & Clcnka & -2.398613973 & 0.017167249 \\
\hline Frzb & -1.87411723 & 0.018244063 & Pkp3 & -2.392942641 & 0.012595497 \\
\hline 4933426D04Rik & -1.873191358 & 0.002186083 & Wdr86 & -2.376940462 & 0.024303922 \\
\hline Female up & & & Male up & & \\
\hline Nccrp1 & 2.445511901 & 0.015416852 & Gm8399 & 3.50912188 & 0.001241839 \\
\hline Gm15178 & 2.333921875 & 0.009174014 & Gm13189 & 3.439868478 & 0.002654011 \\
\hline Fam159b & 2.307178789 & 0.005304213 & Gm3636 & 2.947915088 & 0.001976213 \\
\hline Ghsr & 2.214274204 & 0.046910918 & Gm5915 & 2.695650565 & 0.010436352 \\
\hline$L c t \mid$ & 2.206042282 & 0.003435926 & Fam183b & 2.613476106 & 0.000443822 \\
\hline 5830403M04Rik & 2.196357819 & 0.01632869 & Snord107 & 2.504122381 & 0.006862771 \\
\hline Morn3 & 2.195286458 & 0.016634419 & Gm17645 & 2.424392771 & 0.015338314 \\
\hline Gm12841 & 2.178963909 & 0.023103044 & Oas1a & 2.403928046 & 0.005717344 \\
\hline Muc4 & 2.156227971 & 0.046397596 & Gm8281 & 2.39576758 & 0.009321205 \\
\hline AC153147.1 & 2.065958759 & 0.039141575 & Tmem212 & 2.374337295 & 0.009727819 \\
\hline Gm12970 & 2.059553572 & 0.011745348 & Gm6030 & 2.281421602 & 0.009890373 \\
\hline SIC22a7 & 2.050508464 & 0.015854286 & Gm14027 & 2.266149588 & 0.016576487 \\
\hline Lsm3 & 2.036374973 & 0.012540967 & Ifitm6 & 2.237713216 & 0.028811406 \\
\hline $\operatorname{Trp} 53 \operatorname{tg} 5$ & 2.015448642 & 0.022799387 & Gm17210 & 2.201291602 & 0.007395269 \\
\hline Gm14027 & 2.000153184 & 0.032909893 & Gm11160 & 2.184258988 & 0.010804558 \\
\hline Cd11 & 1.999290666 & 0.03748544 & $75 K$ & 2.138252467 & 0.015927376 \\
\hline Histih4i & 1.995495403 & 0.032921574 & 9030025P20Rik & 2.120186917 & 0.024628307 \\
\hline Fam115c & 1.984655117 & 0.004331027 & 4932411N23Rik & 2.078502283 & 0.027761728 \\
\hline Uncx & 1.955945635 & 0.025358013 & Calca & 2.052551148 & 0.028201798 \\
\hline RP24-372P19.10.1 & 1.951580501 & 0.024900192 & Gm11418 & 2.022765318 & 0.032107609 \\
\hline
\end{tabular}

pared with nonstressed controls (Fig. 2a). In males, $40 \%$ of genes were upregulated, whereas the remainder $(60 \%)$ were downregulated compared with nonstressed controls (Fig. $2 b$ ). Only $\sim 3 \%$ of the genes regulated by stress in females significantly overlapped with the same genes in males regardless of the direction of transcriptional changes (upregulated, $p=$ $3.62 \mathrm{E}^{-8}$; downregulated, $p=4.72 \mathrm{E}^{-10}$; Fig. $\left.2 c, d\right)$. Even fewer genes were oppositely regulated by stress $(0.5 \%)$ in males and females (data not shown, $p>0.05$ ). Examination of the most differentially expressed genes by stress within each sex indicated that only one gene, GM14027, was upregulated in both males and females (Table 1). These data indicate that, rather than the same genes being either commonly or even oppositely regulated by stress in males and females, different molecular cascades are sex-specifically associated with the stress response. Examination of the gene ontology of regulated transcripts indicated that for the top 10 enriched networks $\sim 40 \%$ were regulated in both sexes; however, different sets of specific genes were regulated within these similar networks (Fig. 2e).
DNA methyltransferase 3a is altered in NAc by SCVS in mice and major depressive disorder in humans

A potential mechanism contributing to sex differences in transcriptional profiles is DNA methylation. Dnmts are enzymes involved in catalyzing the addition of a methyl group to the 5 -position on cytosine. Addition of this methyl group can lead to direct transcriptional silencing by occluding transcription factor binding sites, although more recent research has demonstrated more complex roles for DNA methylation in transcriptional control (Hervouet et al., 2009; Baubec et al., 2015; Schübeler, 2015). Dnmt1 maintains previous methylation patterns in daughter cells by methylating hemi-methylated sites, whereas Dnmt3a and $3 \mathrm{~b}$ are involved in de novo methylation (Bestor, 2000; Robertson and Wolffe, 2000). Dnmt expression has been shown to differ during development in males and females, leading to masculinization and feminization of brain structures (McCarthy et al., 2009; Nugent et al., 2015). Furthermore, there is evidence that in males Dnmt3a contributes to susceptibility to social stress and drugs of abuse (LaPlant et al., 2010). We found here that mRNA 

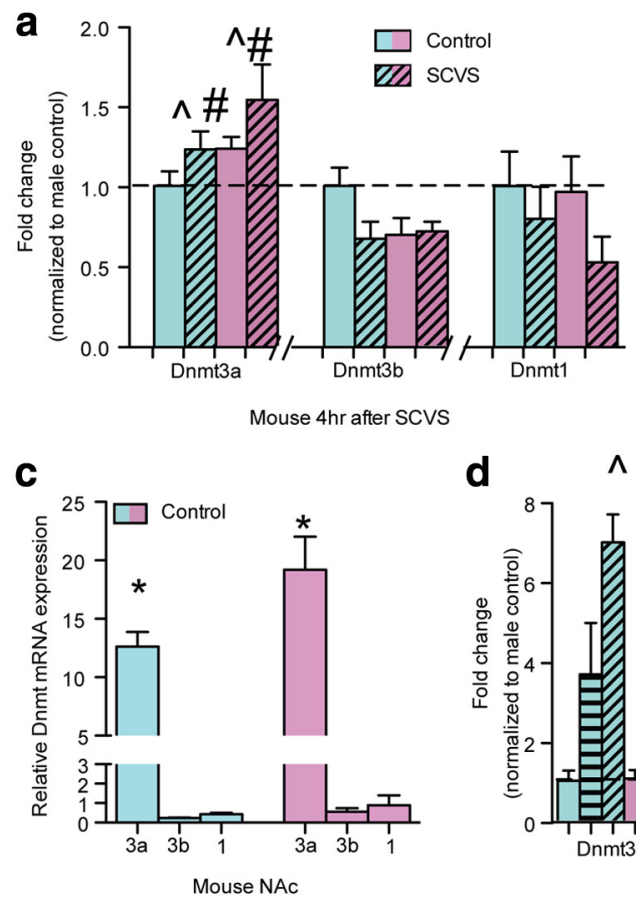

d

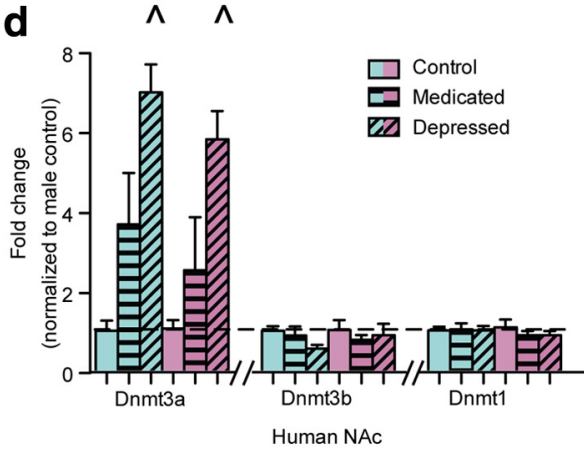

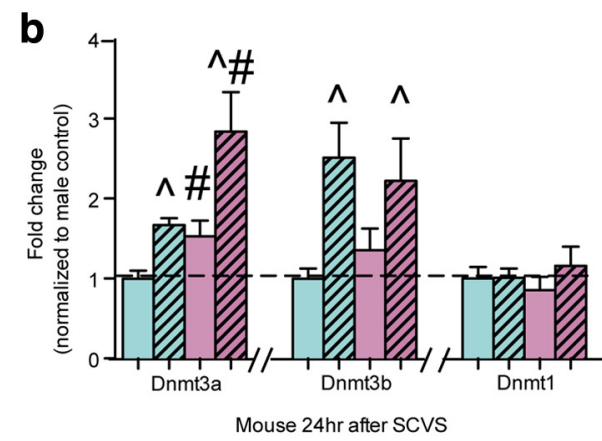

e

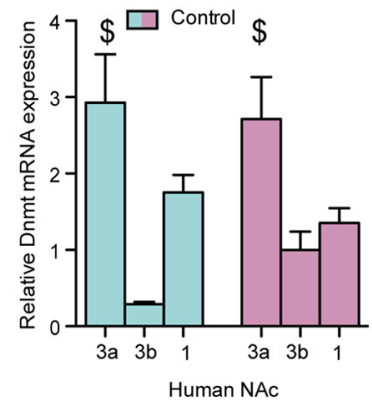

Figure 3. Increased Dnmt3a expression in NAc after SCVS and in major depressive disorder. $\boldsymbol{a}$, Four hours after SCVS, Dnmt3a was the only Dnmt with increased expression in the NAc of both sexes. Overall, females exhibited greater Dnmt3a expression than males ( $n=8 / \mathrm{sex} /$ group). $\boldsymbol{b}$, SCVS increased Dnmt3a expression in the NAc of males and females $24 \mathrm{~h}$ after stress ( $n=8$ or $9 / \mathrm{sex} / \mathrm{group}$ ), but to a larger extent in females. Dnmt3b, but not Dnmt1, was increased by SCVS in the NAc of both males and females. $c$, Examination of Dnmts normalized to the average of all male controls indicated that Dnmt 3a expression was higher than all other Dnmts, a further elevation of Dnmt3a was found in females. $\boldsymbol{d}$, Dnmt3a expression was increased in NAc of depressed humans regardless of sex $(n=4-11$ sex/stress). Antidepressant treatment partially reversed this effect. No other Dnmts were altered by sex, depression, or medication.e, In humans, Dnmt $3 a$ was expressed at a higher level than all other Dnmts in both males and females. *Significant interaction. ^Main effect of stress/depression. ${ }^{\#}$ Main effect of sex. ${ }^{\$}$ Main effect of Dnmt. Data were analyzed by two-way ANOVA.

levels for Dnmt3a were increased in the NAc of both male and female mice by SCVS at both $4 \mathrm{~h}\left(F_{(1,26)}=4.64, p=0.04\right.$; Fig. $\left.3 a\right)$ and $24 \mathrm{~h}\left(F_{(1,27)}=12.26, p=0.0016\right.$; Fig. $\left.3 b\right)$ after stress exposure. We also found a main effect of sex on Dnmt3a, where female mice had overall higher Dnmt3a levels in NAc compared with male mice under combined control and SCVS conditions at $4 \mathrm{~h}$ $\left(F_{(1,26)}=4.79, p=0.03\right)$ and $24 \mathrm{~h}$ after the stressor $\left(F_{(1,27)}=9.07\right.$, $p=0.0056)$. We examined expression of Dnmt $3 \mathrm{~b}$ and Dnmt 1 to determine whether these enzymes might also contribute to sex differences in the effects of stress on the NAc transcriptome. There was no significant effects of stress or sex on Dnmt3b expression $4 \mathrm{~h}$ after SCVS $(p>0.05)$. Dnmt3b was equally elevated by stress in both sexes $24 \mathrm{~h}$ after SCVS $\left(F_{(1,24)}=10.27, p=0.003\right)$, whereas Dnmt1 was not significantly affected by stress in male or female mice either 4 or $24 \mathrm{~h}$ after SCVS ( $p>0.05$ ). Additionally, we compared expression of Dnmt3a directly with Dnmt3b and Dnmtl at the 4 and $24 \mathrm{~h}$ time periods in controls. We normalized all data to average Dnmt levels expressed in control males for each time point. Two-way ANOVA was used to examine Dnmt expression by sex. We found a significant interaction between Dnmt expression and sex at $4 \mathrm{~h}\left(F_{(2,42)}=3.55, p=0.037\right.$; data not shown $)$ and $24 \mathrm{~h}\left(F_{(2,41)}=4.47, p=0.017\right.$; Fig. 3c) Post hoc analysis indicated that at both time points Dnmt 3 a was expressed at higher levels than all other Dnmts in both males and females but to a greater degree in females than in males.

Dnmt3a was not significantly elevated by SCVS in the medial prefrontal cortex (mPFC) of mice ( $p>0.05$, data not shown), suggesting that stress does not globally upregulate Dnmt3a equally in all areas of the brain. However, future research will need to determine whether stress affects Dnmt3a expression in other stress-related brain regions, such as the central nucleus of the amygdala and the hippocampus. An increase in Dnmt3a expression was seen in the NAc of humans with major depressive disorder $\left(F_{(2,36)}=10.71, p=0.0002\right.$; Fig. $\left.3 d\right)$, with a trend for antidepressant treatment to partially reverse this abnormality. We did not observe a main effect of sex on Dnmt3a levels in human NAc tissue, as was the case for mice. We also did not find any significant increase in expression of Dnmt $3 b$ or Dnmt 1 in the NAc of depressed patients $(p>0.05)$. Examination of relative expression of Dnmts in control patients indicated that only Dnmt3a expression was elevated in NAc of both males and females $\left(F_{(2,33)}=64.33, p<0.0001\right.$; Fig. $\left.3 e\right)$.

\section{Overexpression of Dnmt3a makes both sexes susceptible to subthreshold variable stress}

In male mice, viral-mediated overexpression of Dnmt3a in the NAc has been shown to induce a prosusceptible behavioral phenotype in response to a subthreshold form of social defeat stress (LaPlant et al., 2010). Here we expressed HSV-Dnmt3a or -green fluorescent protein (GFP/control) in the NAc (Fig. 4a) of male and female mice and exposed all animals to a $3 \mathrm{~d}$ STVS. Overexpression of Dnmt3a by HSV resulted in a significant increase in Dnmt3a expression $3 \mathrm{~d}$ after viral injection $\left(F_{(1,19)}=44.38, p<\right.$ 0.0001; Fig. 4b). Mice injected with HSV-Dnmt3a exhibited 6-fold to 8-fold higher levels of Dnmt3a than those injected with HSV-GFP, with approximately comparable induction seen in the two sexes. Although STVS was not sufficient to induce depression- or anxiety-associated behavior in either sex injected intra-NAc with HSV-GFP, both male and female mice injected intra-NAc with HSV-Dnmt3a displayed a stress susceptible phenotype across all behavioral measures. Dnmt3a overexpression decreased grooming in the splash test (Fig. $4 c$ ) as indicated by a 

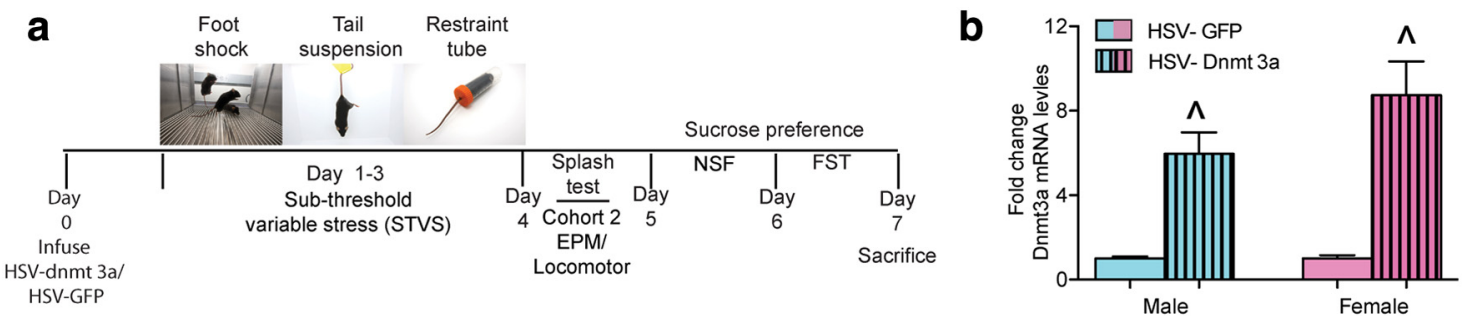

C
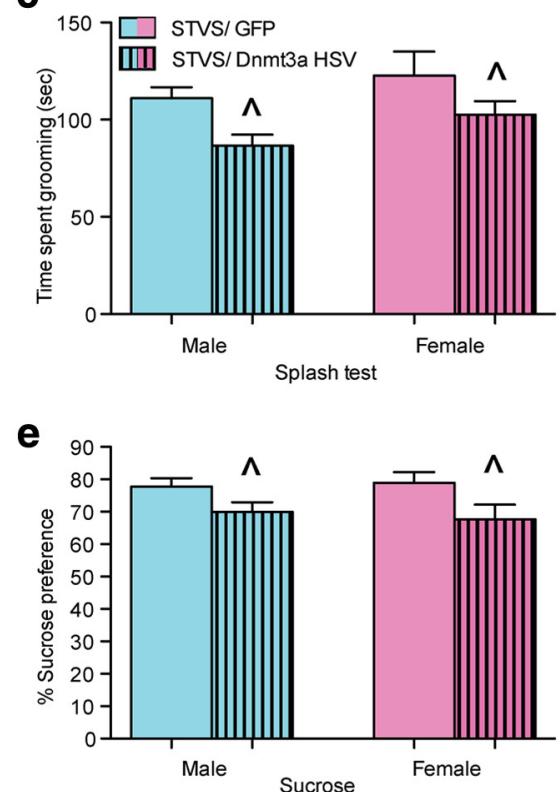

g

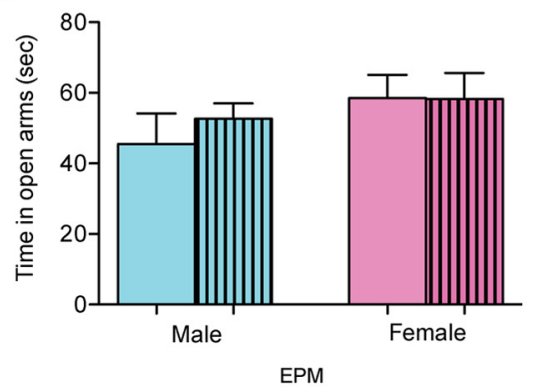

d

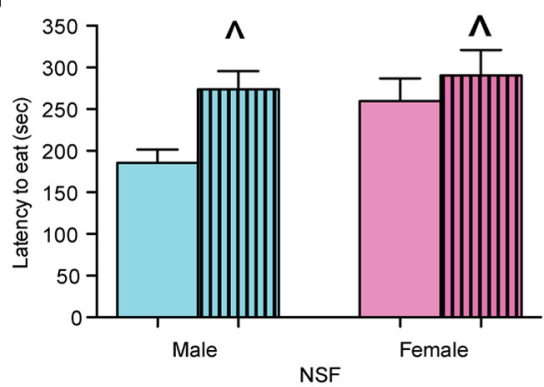

f

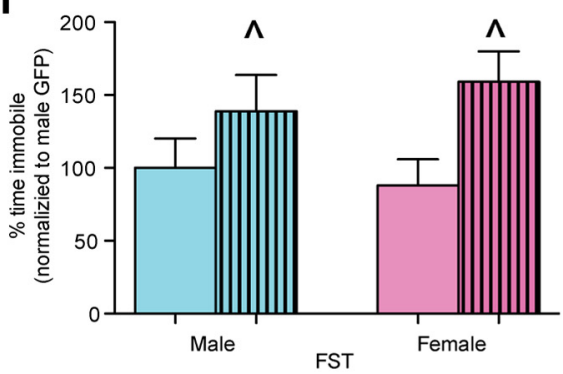

h

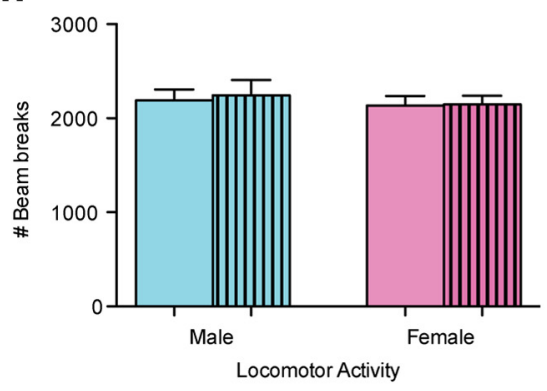

Figure 4. Overexpression of Dnmt3a in NAc is sufficient to induce depression- and anxiety-associated behaviors in males and females exposed to STVS. $\boldsymbol{a}$, Schematic of the $3 \mathrm{~d}$ STVS procedure and behavioral testing schedule. $\boldsymbol{b}$, Validation of viral-mediated overexpression of HSV-Dnmt3a by mRNA expression in NAc. $\boldsymbol{c}$, Overexpression of Dnmt3a in NAc decreased time grooming in the splash test in both males and females. $\boldsymbol{d}$, Dnmt3a overexpression increased latency to eat in a novel environment in both males and females. $\boldsymbol{e}, 0$ verexpression of Dnmt 3 a decreased sucrose preference in both males and females. $\boldsymbol{f}$, Overexpression of Dnmt3a increased percentage of time spent immobile in the FST in both sexes ( $n=9$ or 10/sex/virus). ${ }^{\wedge}$ Main effect of virus (two-way ANOVA). $\boldsymbol{g}$, Dnmt3a overexpression or sex did not alter time spent in the open arm of the EPM. $\boldsymbol{h}$, There were no effects of Dnmt3a overexpression or sex on locomotor activity.

main effect of virus $\left(F_{(1,34)}=7.8, p=0.008\right)$, increased latency to eat in the NSF test (Fig. $4 d$ ) as indicated by a main effect of virus $\left(F_{(1,34)}=5.73, p=0.02\right)$, decreased sucrose preference $\left(F_{(1,34)}=\right.$ 7.4, $p=0.01$; Fig. $4 e)$, and increased passive coping responses (Fig. $4 f)$ in the FST $\left(F_{(1,34)}=6.64, p=0.01\right)$. Overexpression of Dnmt3a in NAc followed by STVS did not lead to sex or stress differences in exploratory anxiety-associated behavior in the EPM ( $p>0.05$; Fig. $4 f)$ or locomotor activity ( $p>0.05$; Fig. $4 g)$.

\section{Dnmt3a knock-out in the female NAc promotes behavioral resilience to SCVS}

As overexpression of Dnmt3a was sufficient to induce a stress susceptible state in both sexes, we next tested whether the enzyme was also necessary for the greater susceptibility of female mice to
SCVS. Male and female Dnmt3a $\mathrm{a}^{2 \mathrm{lox} / 2 \mathrm{lox}}$ mice were injected intraNAc with AAV-Cre to knock-out Dnmt3a expression specifically in adult NAc neurons, which we confirmed experimentally (Fig. $5 a, b$; main effect of virus, $F_{(1,29)}=13.38, p=0.001$ ). After a previously validated 2 week period of recovery to allow for viral expression (Feng et al., 2010; LaPlant et al., 2010), animals were exposed to $6 \mathrm{~d}$ of SCVS. Female mice that were given injections of AAV-GFP exhibited depression-associated behaviors (similar to responses seen in SCVS females in Fig. 1), whereas knock-out of Dnmt $3 a$ in the NAc of adult females promoted resilience. Stressed AAV-GFP injected females displayed decreased grooming behavior, whereas knock-out of Dnmt3a increased time spent grooming to male-like levels $\left(F_{(1,33)}=14.56, p=0.0006\right.$; Fig. $\left.5 c\right)$. SCVS increased the latency to eat in the NSF test in AAV-GFP injected 

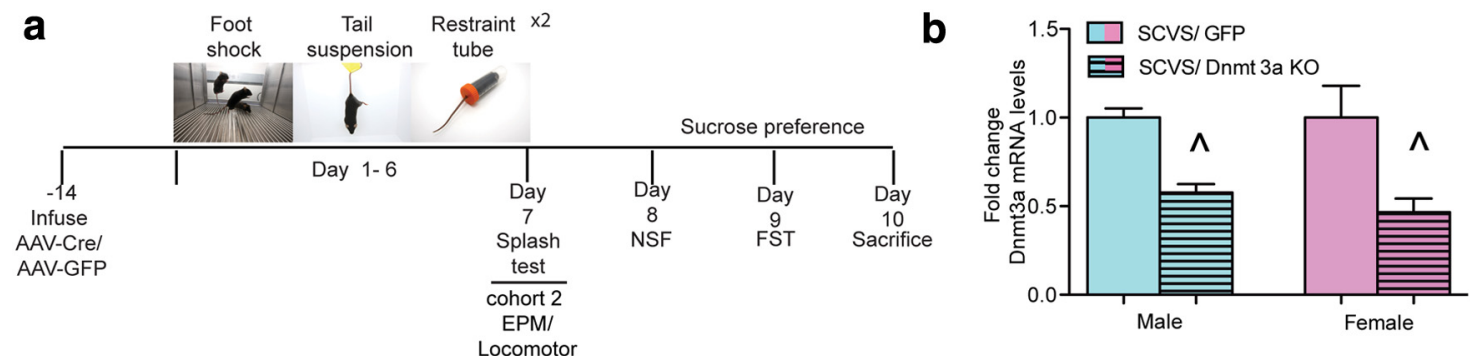

C

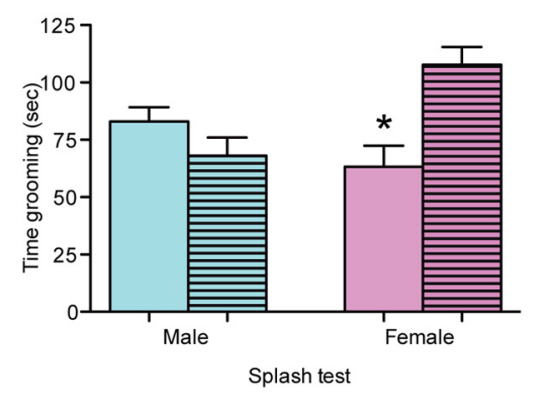

e

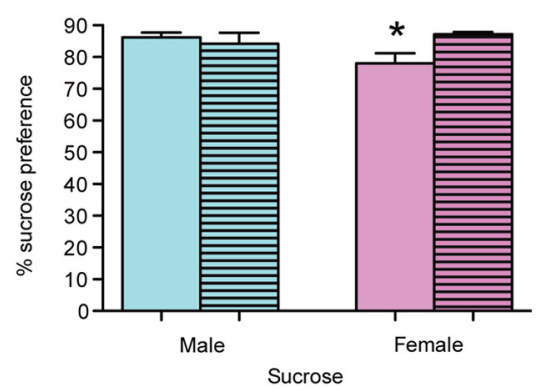

g

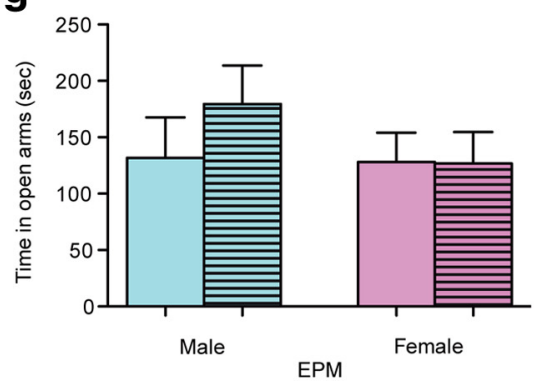

d
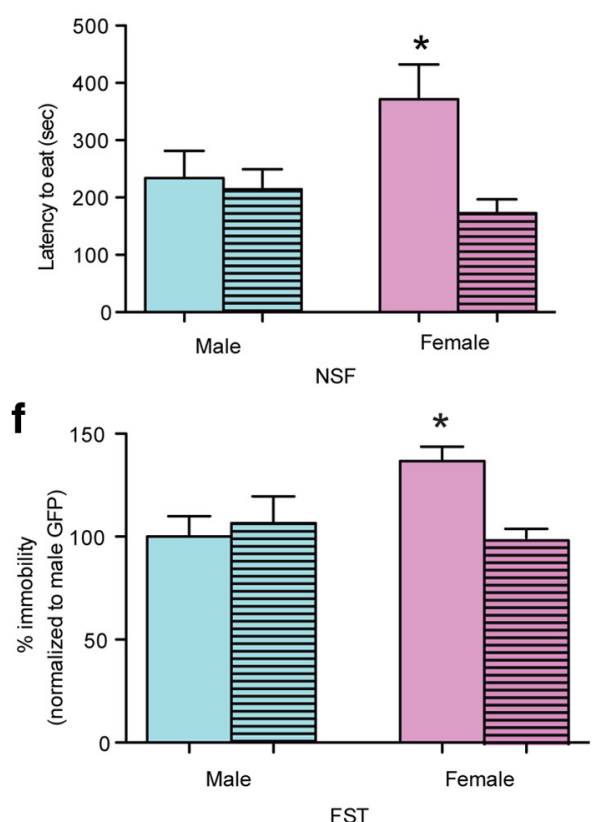

h

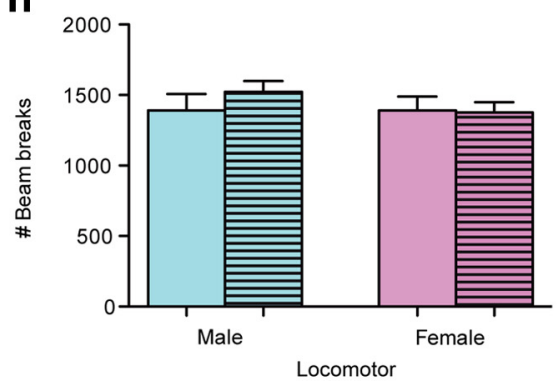

Figure 5. Dnmt3a knock-out from NAc in females promotes resilience to SCVS. $\boldsymbol{a}$, Schematic of surgery, SCVS procedure, and behavioral testing. $\boldsymbol{b}$, Validation of Dnmt3a knock-out by mRNA expression levels in NAc ( $n=5-11$ per condition). c, Dnmt3a knock-out from NAc blocks the decrease in grooming caused by ScVS in females $(n=8-11 /$ sex/virus for behavioral testing). $\boldsymbol{d}$, Dnmt3a knock-out from NAcblocks the increased latency to eat in the novelty suppressed feeding test in females. $\boldsymbol{e}$, Dnmt3a knock-out from NAcblocks the decreased sucrose preference in females. $\boldsymbol{f}$, Dnmt3a knock-out from NAc blocks the increase in passive coping in the FST in females. No effect of Dnmt3a knock-out was evident in males. $\boldsymbol{g}$, There was no effect of excising Dnmt3a or sex on anxiety associated exploratory behavior in the EPM. $\boldsymbol{h}$, There were no effects of Dnmt3a knock-out or sex on locomotor activity. *Significant interaction between sex and virus (two-way ANOVA followed by Bonferroni post hoc analysis).^ indicates a main effect of virus.

females, but knock-out of Dnmt3a reversed this effect $\left(F_{(1,33)}=\right.$ 4.35, $p=0.04$; Fig. $5 d$ ). Stressed AAV-GFP injected females showed a decrease in sucrose preference that was blocked by knock-out of $\operatorname{Dnmt3a}\left(F_{(1,33)}=6.41, p=0.01\right.$; Fig. $\left.5 e\right)$. Knockout of Dnmt3a in females also increased active coping response in the $\operatorname{FST}\left(F_{(1,33)}=6.13, p=0.01\right.$; Fig. $\left.5 f\right)$. In striking contrast to female mice, male mice exhibited no significant behavioral effects upon NAc knock-out of Dnmt3a as they were already resilient to SCVS. In a separate cohort of animals, we demonstrated that NAc specific knock-out of Dnmt3a had no effect on exploratory anxiety-associated behavior in the EPM or on locomotor activity following SCVS ( $p>0.05$; Figs. $5 g, h$ ).
Dnmt3a knock-out in female NAc creates a mixture of maleand female-like transcriptional responses to SCVS

Based on these findings that Dnmt3a knock-out from the NAc induces behavioral resilience to SCVS in females, making them behaviorally resemble males, we next examined the effects of Dnmt3a knock-out on NAc transcriptional responses to SCVS in both sexes. The goal was to determine whether stressed females without Dnmt3a in NAc are transcriptionally similar to resilient stressed males or whether Dnmt3a knock-out affected distinct sets of genes in females. Adult male and female Dnmt $3 a^{2 \text { lox } / 2 \text { lox }}$ were injected intra-NAc with AAV-Cre or AAV-GFP and allowed 2 weeks for maximal viral expression. All animals were subjected 


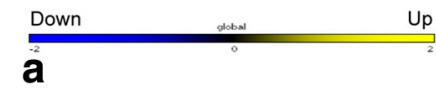

\section{p}
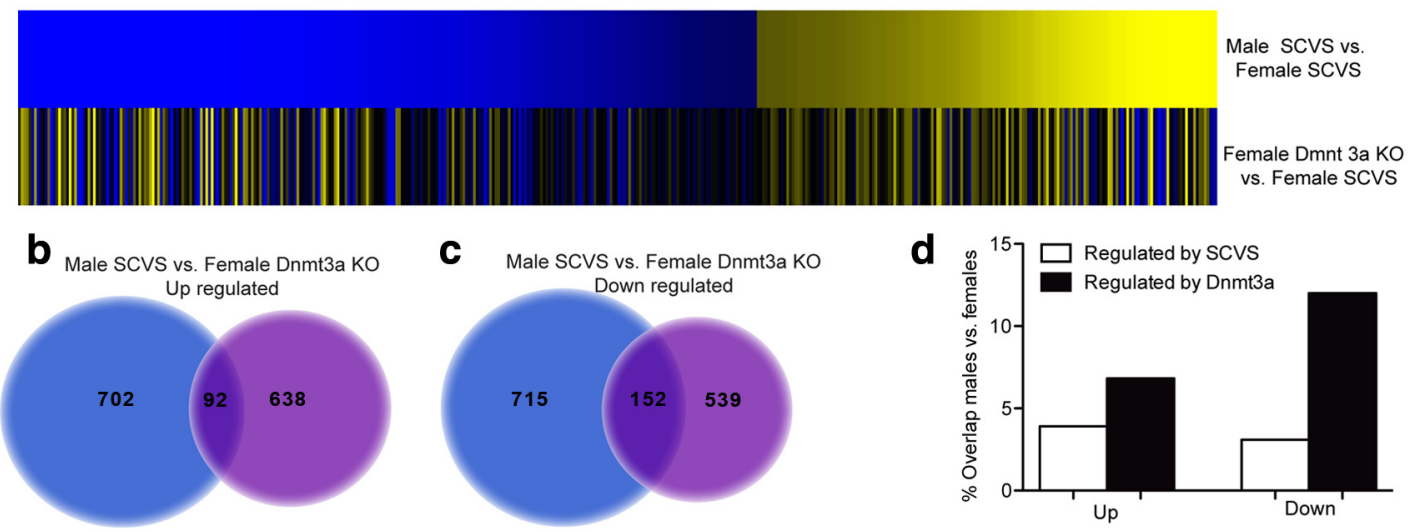

e

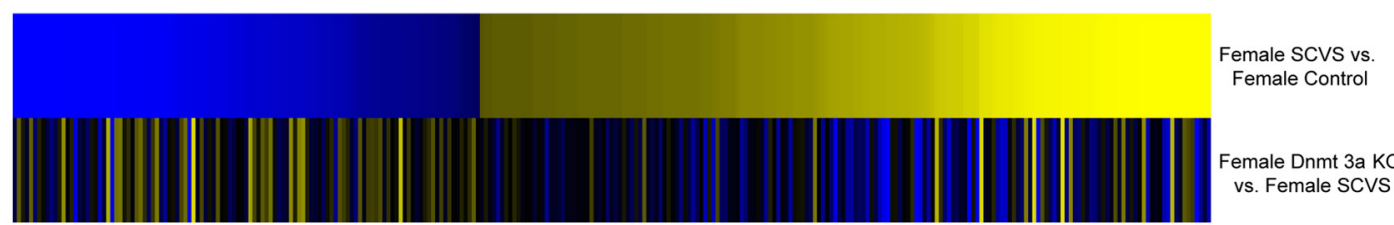

$\mathbf{f}$

g

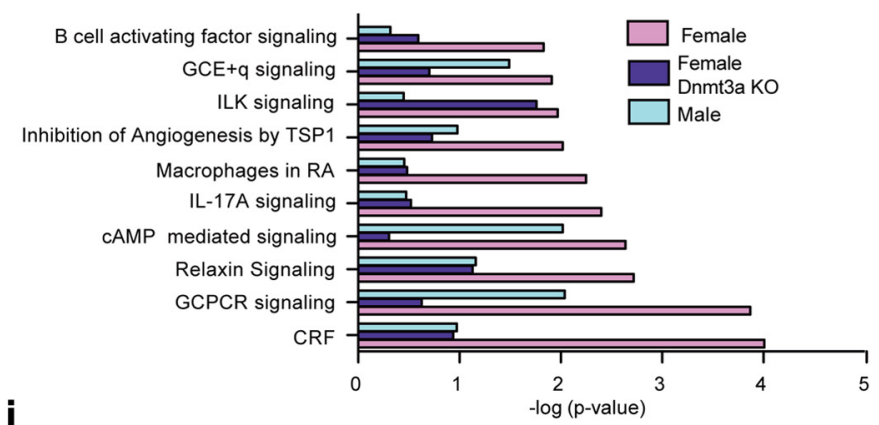

i

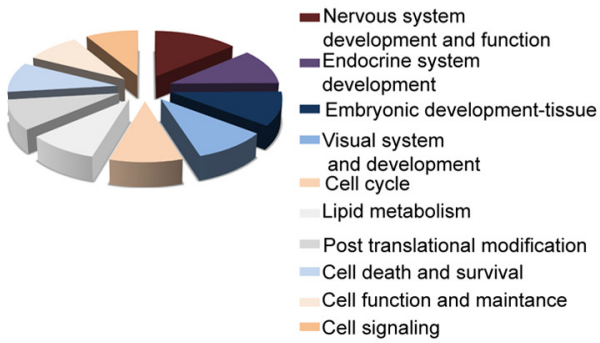

h
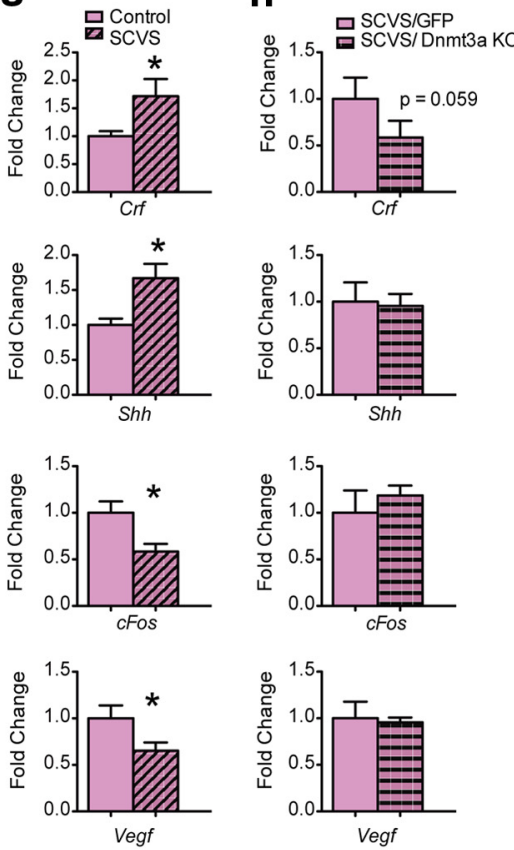

Figure 6. Dnmt3a knock-out from NAc in females creates a hybrid male/female transcriptional state in this brain region. $\boldsymbol{a}$, Heatmap of genes differentially expressed in Dnmt3a knock-out females compared with GFP males that underwent SCVS. $\boldsymbol{b}$, Comparison of genes upregulated in males and Dnmt3a knock-out females. $\boldsymbol{c}$, Comparison of genes downregulated in males and Dnmt3a knock-out females. $\boldsymbol{d}$, Comparison of the percentage of genes that overlap in SCVS males and females with the overlap in SCVS males and Dnmt3a knock-out females. $\boldsymbol{e}$, Heatmap of genes differentially regulated by SCVS females compared with Dnmt3a knock-out females. Dnmt3a knock-out neutralizes a subset of genes regulated by stress in females. $f$, Canonical pathways altered by SCVS in females compared with the same pathways in Dnmt3a knock-out SCVS females and stressed males. $\boldsymbol{g}$, Validation by qRT-PCR of a subset of genes regulated by SCVS in females from the CRF pathway ( $n=9-17 /$ gene/condition). $\boldsymbol{h}$, Genes regulated by SCVS in the CRF pathway are neutralized by removing Dnmt3a ( $n=5-8 /$ gene/condition). $\boldsymbol{i}$, Network analysis of Dnmt3a knock-out females. Libraries were created from pooled mRNA samples ( $n=4$ mice/library and run in independent biological replicates of 3 libraries per sex/stress). *Significant difference in means (unpaired $t$ test, two tailed).

to our standard $6 \mathrm{~d}$ SCVS procedure, after which NAc was analyzed by RNA-seq. We first compared SCVS males that were injected intra-NAc with AAV-GFP to SCVS females that were injected with AAV-GFP to obtain a direct measure of genes that differed in stressed males versus stressed females. Genes that differed between stressed females with or without Dnmt $3 a$ were then overlapped with the genes that differed in males to determine whether the same or different genes were altered by removing Dnmt3a. Dnmt3a knock-out increased the number of genes that were similarly regulated in stressed males and females (Fig. 6a). When genes that were upregulated by stress were examined, 7\% now overlapped ( $p=9.72 \mathrm{E}^{-30}$; Fig. $\left.6 b\right)$, a doubling of the per- 
Table 2. Top 20 genes upregulated or downregulated in Cre females or GFP males compared to GFP females

\begin{tabular}{|c|c|c|c|c|c|}
\hline Gene name & Fold change & $p$ value & Gene name & Fold change & $p$ value \\
\hline Female Cre down & & & Male GFP down & & \\
\hline 2610028E06Rik & -3.815669518 & 0.017359782 & Xist & -8.259140012 & $1.05837 \mathrm{E}-09$ \\
\hline Glra1 & -3.777861453 & 0.030384424 & Igkv8-28 & -3.550788842 & 0.02367806 \\
\hline Igkv8-28 & -3.562110487 & 0.016379099 & Faim3 & -3.306933496 & 0.006216687 \\
\hline B230323A14Rik & -3.308855277 & 0.026720521 & 2610028E06Rik & -3.215167466 & 0.025869938 \\
\hline $\operatorname{lgkv5}-39$ & -3.083576343 & 0.036797559 & Lhx1 & -2.865336895 & 0.031223676 \\
\hline Cckar & -3.006809571 & 0.027101278 & 2310002F09Rik & -2.814260238 & 0.024515479 \\
\hline Sele & -2.846736277 & 0.010806681 & Ehf & -2.767847632 & 0.045858546 \\
\hline lghg3 & -2.804610748 & 0.010727642 & 2210011C24Rik & -2.767673108 & 0.004131266 \\
\hline Gm16252 & -2.691979674 & 0.00195677 & Gm16976 & -2.71308896 & 0.007648211 \\
\hline Alox $12 b$ & -2.598936224 & 0.010117621 & Rgs 18 & -2.691120291 & 0.020928227 \\
\hline Gm12747 & -2.519836925 & 0.021968674 & $R \ln 3$ & -2.625870358 & 0.003611995 \\
\hline Gm16401 & -2.512830676 & 0.00208992 & A530064D06Rik & -2.588128519 & 0.003138544 \\
\hline Cyp4b1 & -2.493920227 & 0.010978487 & Gm3834 & -2.539356979 & 0.035034302 \\
\hline Npy6r & -2.483696671 & 0.019981522 & Gm17520 & -2.517633615 & 0.004545332 \\
\hline U2 & -2.446695181 & 0.028304407 & $S / c 34 a 3$ & -2.506518237 & 0.001863757 \\
\hline$S / C 4 a 9$ & -2.385856308 & 0.024373721 & Ngfr & -2.46485725 & 0.043090368 \\
\hline Oas7e & -2.34019553 & 0.00853881 & Lct & -2.452082424 & 0.019612826 \\
\hline Gm16976 & -2.324590663 & 0.014526474 & $K 1 k 9$ & -2.447560443 & 0.045316358 \\
\hline Krt7 & -2.298562326 & 0.020356266 & 4921504E06Rik & -2.378338957 & 0.01713679 \\
\hline Olfr755-ps1 & -2.275516392 & 0.035771784 & Gm16094 & -2.302795621 & 0.004955431 \\
\hline Female Cre up & & & Male GFP up & & \\
\hline Mir5105 & 3.095955764 & 0.003375303 & Mir5113 & 2.408937738 & 0.029911658 \\
\hline lgkv15-103 & 3.070102627 & 0.03234545 & 4930566N20Rik & 2.398372862 & 0.029877806 \\
\hline mmu-mir-689-2 & 2.943636188 & 0.002483928 & 4832428D23Rik & 2.387807986 & 0.029843954 \\
\hline Ighv10-3 & 2.931813135 & 0.016063254 & Cxc118 & 2.377243109 & 0.029810102 \\
\hline Mir5133 & 2.87966306 & 0.008377912 & Gm14105 & 2.366678233 & 0.02977625 \\
\hline Vnn1 & 2.858931436 & 0.010690621 & Tekt4 & 2.356113357 & 0.029742398 \\
\hline RNase_MRP & 2.681722316 & 0.034451817 & Rfpl3s & 2.34554848 & 0.029708545 \\
\hline 4930563E18Rik & 2.500978593 & 0.004662084 & Gm4708 & 2.334983604 & 0.029674693 \\
\hline lghv1-67 & 2.482869688 & 0.018854356 & 4930542H2ORik & 2.324418728 & 0.029640841 \\
\hline 2010001K21Rik & 2.465678441 & 0.005986163 & Gm17062 & 2.313853851 & 0.029606989 \\
\hline$G m 4242$ & 2.396053847 & 0.017873781 & Gm17193 & 2.303288975 & 0.029573137 \\
\hline Hist1h4j & 2.342766098 & 0.001688654 & Adam29 & 2.292724099 & 0.029539285 \\
\hline Gm12977 & 2.333234277 & 0.022847111 & Gm15492 & 2.282159222 & 0.029505433 \\
\hline Gm13480 & 2.29376431 & 0.021635415 & Gm12088 & 2.271594346 & 0.029471581 \\
\hline 2810430111Rik & 2.270181105 & 0.018149357 & Gm14776 & 2.26102947 & 0.029437729 \\
\hline Gm2044 & 2.264925193 & 0.004171032 & Abca15 & 2.250464593 & 0.029403877 \\
\hline Gm17384 & 2.228287668 & 0.031399265 & Gm23327 & 2.239899717 & 0.029370025 \\
\hline Cdkn2a & 2.224762948 & 0.021933978 & Gm17387 & 2.229334841 & 0.029336173 \\
\hline$G m 13540$ & 2.219427837 & 0.022772603 & Olfr544 & 2.218769964 & 0.029302321 \\
\hline Tekt3 & 2.183591197 & 0.012480037 & Gm12695 & 2.208205088 & 0.029268469 \\
\hline
\end{tabular}

centage of genes that were similarly upregulated by stress in the presence of Dnmt3a (Fig. 6d). When downregulation of transcription was compared in stressed males and females lacking Dnmt3a, $12 \%$ of genes now overlapped ( $p=4.95 \mathrm{E}^{-90}$; Fig. $6 c$ ); this represents a tripling of the genes commonly downregulated in NAc by SCVS in males and females (Fig. $6 d$ ). Examination of the top 20 most regulated gene products indicated that three were downregulated by SCVS in both stressed males and Dnmt3a knock-out females (Table 2). To determine which genes regulated by SCVS in females were affected by removal of Dnmt3a, we compared gene profiles from the first RNA-seq experiment (Stress/Control) with the second RNA-seq experiment (Stress with/without Dnmt3a). We found that, in females, removal of Dnmt3a led to neutralization of transcription regardless of whether these genes were activated or suppressed by stress (Fig. $6 e)$.

Next, we examined how Dnmt3a knock-out in the female NAc altered the top 10 gene ontology pathways that were regulated by stress. Using Ingenuity pathway analysis, we explored whether patterns of gene expression in NAc lacking Dnmt3a resembled wild-type males that were stressed (i.e., resilience) or wild-type females that were stressed (i.e., susceptibility). Seven of the top 10 canonical pathways affected by SCVS in wild-type females were changed to male levels upon Dnmt3a knock-out (Fig. 6f). For example, multiple genes in the corticotrophin releasing factor (Crf) pathway (Fig. $6 g$ ) were regulated by stress, including those encoding $\operatorname{Crf}\left(t_{(24)}=2.07, p=0.04\right), \operatorname{Shh}\left(t_{(22)}=2.18, p=0.01\right)$, $\operatorname{cFos}\left(t_{(17)}=2.76, p=0.01\right)$, and $\operatorname{Vegf}\left(t_{(27)}=2.07, p=0.04\right)$; regulation of all of these genes was neutralized upon Dnmt3a knock-out (Fig. 6h). Other highly regulated gene ontology pathways in females neutralized by Dnmt $3 a$ knock-out included immune factors, such as macrophages in rheumatoid arthritis and interleukin-17 signaling. Increased immune activation has been associated with susceptibility in males following chronic social stress (Hodes et al., 2014) and may also play an important role in female stress susceptibility. Integrin-linked kinase signaling, which is involved in cell migration, proliferation, adhesion, and signal transduction (Yoganathan et al., 2002), was the only canonical pathway in which transcription patterns did not change following Dnmt3a removal in females. Overall, network analysis 
of Dnmt3a knock-out females exposed to SCVS demonstrated that $40 \%$ of networks continued to resemble those altered by SCVS in wild-type females compared with their nonstressed controls and $30 \%$ of the affected networks now resembled males, with the remaining $30 \%$ affecting different networks in the two sexes (Fig. 6i). Together, these data indicate that removal of Dnmt3a from the NAc blocks a portion of the transcriptional effects of stress in females to show a greater similarity to the male pattern that is associated with resilience. However, at the same time, there are numerous other pathways to resilience in the Dnmt3a knock-out condition that appear to be female-specific. Therefore, removal of Dnmt3a in the NAc leads to a hybrid male/ female transcriptional state.

\section{Discussion}

Results of the present study demonstrate that male and female mice exposed to the same stressors show different behavioral responses and transcriptional regulation of the NAc, a brain area involved in reward and emotional processing. Expression of the DNA methyltransferase Dnmt3a, but not Dnmt3b or Dnmt1, was significantly elevated in the NAc of both humans with major depressive disorder and mice exposed to SCVS within 4-24 h after the last stressor. In both males and females, overexpression of Dnmt3a in NAc was sufficient to induce increased susceptibility to a subthreshold form of stress. Conversely, the selective knock-out of Dnmt3a from the female NAc was sufficient to induce male-like resilience to SCVS as well as a more male-like transcriptional response in NAc after SCVS. Several prominent molecular cascades that were activated by SCVS to a greater extent in the female NAc were neutralized by removal of Dnmt3a from this brain region. Together, these data provide new insight into the molecular basis of the greater stress susceptibility seen in females.

\section{Females are behaviorally susceptible to SCVS, whereas males are resilient}

We demonstrate that the SCVS paradigm induces several behavioral deficits in female, but not male, mice across a test battery of depression-associated behaviors. Although a higher incidence of depression is known to occur in women (Kessler, 2003), there are few animal models that demonstrate this greater susceptibility to stress. Indeed, several currently studied stress models are difficult to perform or interpret in females. This includes learned helplessness in which females show more active escape behavior (Dalla et al., 2008), and repeated social defeat stress, which can only be performed in certain species of female rodents (Solomon et al., 2007; Trainor et al., 2011) or in lactating females (Ver Hoeve et al., 2013). Because of these limitations, most research into the mechanisms of vulnerability to stress has used male rodents, and currently little is known about the mechanisms involved in sex differences in stress susceptibility. It has generally been assumed that molecular processes in the female brain would mirror that of the male. Here we demonstrate that transcriptional profiles differ almost completely between males and females exposed to SCVS. A limitation of the current study is that we only examine transcriptional profiles at one time point when males and females show differences in behavioral responses and only in one brain region. Future research is needed to determine whether males and females show greater similarities in behavioral and transcriptional profiles at different time points and other brain topography.

\section{SCVS alters different transcriptional pathways in males and females}

Although males do not show behavioral susceptibility to SCVS, they exhibit robust transcriptional changes after stress. Indeed, more genes were regulated in NAc by SCVS compared with unstressed controls in males than in females, and this may reflect a more active transcriptional response that contributes to stress resilience. Few of the genes that were regulated by stress in males overlapped with the same genes regulated by stress in females. The genes that were significantly downregulated in both males and females by stress were for the most part activity-dependent early response genes such as $c F o s, A r c$, and Npas4, many of which have been demonstrated to affect a multitude of different downstream molecular cascades (Spiegel et al., 2014). Genes that were upregulated in both sexes included several involved in G-proteincoupled receptor signaling. Network analysis demonstrated that molecules involved with the cardiovascular system, DNA regulation, cancer and nervous system development and function were among the top 10 networks regulated by stress in both sexes as indicated by enrichment scores. Some networks, such as the cardiovascular system, received similar enrichment scores in both males and females, indicating a similar number of genes in each network were involved, although different genes were activated or suppressed by stress within each sex. Other networks, such as nervous system development and function, were enriched to a much greater degree in females than males. We believe that identification of sex-specific changes in these broad network categories provides a rationale for developing individualized diagnostic tests and treatment strategies for male and female depression.

\section{Dnmt3a in NAc controls behavioral susceptibility to stress}

Both chronic cocaine exposure and repeated social defeat stress increase Dnmt3a expression in NAc of male mice (LaPlant et al., 2010). Dnmt3a is the most abundantly transcribed DNA methyltransferase in NAc of male (LaPlant et al., 2010) and female mice and humans. Here we demonstrate that SCVS increases levels of Dnmt3a in the NAc of both male and female mice at least 4-24 h after stressor cessation. Dnmt3a expression levels in NAc were also increased in humans suffering from major depressive disorder. In both sexes, these effects were partially attenuated by antidepressant treatment. These findings are interesting in light of the recent report that single nucleotide polymorphisms in the human Dnmt3a gene, extracted from peripheral tissues, are associated with the ability to buffer the effects of stress contributing to negative affect (Pishva et al., 2014).

Earlier studies have associated increased Dnmt3a levels in response to maternal stress during the neonatal period with subsequent increased anxiety-like behavior in males through lasting epigenetic regulation of the hypothalamic-pituitary-adrenal axis (Jensen Peña et al., 2012; Wang et al., 2013). Alternatively, early life stress can downregulate Dnmt3a expression in the mPFC of mice, although causal links have not yet been made with depression or anxiety behavior (Blaze and Roth, 2013). In contrast to early life stress, exposure to SCVS on Dmnt3a in adulthood reported here seems to be specific to the NAc as no effects were observed in the mPFC. Further studies will be needed to determine the effects of stress on Dnmt3a levels in subregions of mPFC (infralimbic vs prelimbic) as well as other stress responsive brain regions associated with mood disorders. In adult male animals, overexpression of Dnmt3a in the NAc increased social avoidance behavior following a subthreshold social stress (LaPlant et al., 2010). Here we expand upon these findings and demonstrate that 
Dnmt3a overexpression in NAc functionally contributes to stress susceptibility in both sexes. Males and females were injected intra-NAc with HSV-Dnmt3a and then exposed to 3 d STVS. As females are already susceptible to the $6 \mathrm{~d}$ version of SCVS, we used this subthreshold procedure that normally does not induce depression and anxiety-related behavior to uncover whether the animals had shifted to a more susceptible phenotype. Both males and females overexpressing Dnmt3a in NAc exhibited depression-like behaviors after STVS across a behavioral test battery that included the splash test, NSF, sucrose preference, and FST. Together, these data suggest that the higher transcriptional expression of Dnmt3a is sufficient to induce a stress susceptible state that may be specific to depression-like behavior.

While overexpression of Dnmt3a in the NAc induces stress susceptibility in both males and females, conditional deletion of the Dnmt3a gene from NAc neurons induced behavioral resilience in females. Males do not display behavioral susceptibility to stress under normal conditions and therefore did not show any changes in behavior upon Dnmt3a knock-out. Previous research demonstrated that pharmacologically inhibiting Dnmt3a in NAc, through infusion of RG108, in males susceptible to social defeat stress, reversed avoidance behavior (LaPlant et al., 2010). These effects were similar to those produced by $28 \mathrm{~d}$ of systemic administration of the standard antidepressant fluoxetine (LaPlant et al., 2010), indicating that blocking DNA methylation is antidepressant-like in stressed male animals.

\section{Removing Dnmt3a from the female NAc shifts transcriptional patterns after SCVS}

Although excising Dnmt3a from the NAc made females stress resilient, it was not clear from the behavioral data whether this was due to a more male-like transcriptional pattern in the female NAc upon Dnmt3a knock-out or to distinct transcriptional mechanisms. Therefore, we performed RNA-seq on NAc from separate groups of male and female $D n m t 3 a^{2 l o x / 2 l o x}$ mice that were injected intra-NAc with either AAV-GFP or AAV-Cre and then subjected to SCVS. AAV-GFP-expressing females exposed to SCVS have mostly different patterns of transcriptional activation and suppression than AAV-GFP-expressing males, similar to observations in noninjected SCVS animals (Fig. 2). Removing Dnmt3a from the female NAc, which leads to behavioral resilience, dramatically alters transcriptional profiles in this brain region. Females lacking Dnmt3a from NAc display a hybrid of male and female stress-specific transcriptional profiles. For example, there is a doubling (upregulation) to tripling (downregulation) of the percentage of overlapping genes occurring between stressed males and stressed Dnmt3a knock-out females. These changes in transcription lead to a more male-like expression of canonical pathways, with Dnmt3a knock-out in females inducing a male-like pattern in 7 of the top 10 regulated gene ontology pathways. Despite this partial shift toward male-like patterns, Dnmt3a knock-out from the female NAc also leads to many unique changes in transcription associated with behavioral resilience in the mutant females.

In conclusion, these data demonstrate a sex-specific transcriptional profile in NAc that mirrors sex-specific behavioral stress susceptibility. This transcriptional profile can be altered by removal of the de novo DNA methyltransferase Dnmt3a from this brain region, which creates a hybrid male/female transcriptional pattern. Such removal also induces behavioral resilience to stress in females. These findings shed new light onto molecular factors controlling sex differences in stress responses, the first step in defining therapeutics selective for stress-related disorders in women.

\section{References}

Anders S, Pyl PT, Huber W (2015) HTSeq: a Python framework to work with high-throughput sequencing data. Bioinformatics 31:166-169. CrossRef Medline

Anker JJ, Carroll ME (2011) Females are more vulnerable to drug abuse than males: evidence from preclinical studies and the role of ovarian hormones. Curr Top Behav Neurosci 8:73-96. CrossRef Medline

Autry AE, Adachi M, Cheng P, Monteggia LM (2009) Gender-specific impact of brain-derived neurotrophic factor signaling on stress-induced depression-like behavior. Biol Psychiatry 66:84-90. CrossRef Medline

Bangasser DA, Shors TJ (2008) The bed nucleus of the stria terminalis modulates learning after stress in masculinized but not cycling females. J Neurosci 28:6383-6387. CrossRef Medline

Bangasser DA, Valentino RJ (2012) Sex differences in molecular and cellular substrates of stress. Cell Mol Neurobiol 32:709-723. CrossRef Medline

Baubec T, Colombo DF, Wirbelauer C, Schmidt J, Burger L, Krebs AR, Akalin A, Schübeler D (2015) Genomic profiling of DNA methyltransferases reveals a role for DNMT3B in genic methylation. Nature 520:243-247. CrossRef Medline

Becker JB, Perry AN, Westenbroek C (2012) Sex differences in the neural mechanisms mediating addiction: a new synthesis and hypothesis. Biol Sex Differ 3:14. CrossRef Medline

Beery AK, Zucker I (2011) Sex bias in neuroscience and biomedical research. Neurosci Biobehav Rev 35:565-572. CrossRef Medline

Bestor TH (2000) The DNA methyltransferases of mammals. Hum Mol Genet 9:2395-2402. CrossRef Medline

Blaze J, Roth TL (2013) Exposure to caregiver maltreatment alters expression levels of epigenetic regulators in the medial prefrontal cortex. Int J Dev Neurosci 31:804-810. CrossRef Medline

Bowman RE, Zrull MC, Luine VN (2001) Chronic restraint stress enhances radial arm maze performance in female rats. Brain Res 904:279-289. CrossRef Medline

Bowman RE, Beck KD, Luine VN (2003) Chronic stress effects on memory: sex differences in performance and monoaminergic activity. Horm Behav 43:48-59. CrossRef Medline

Carvalho-Netto EF, Myers B, Jones K, Solomon MB, Herman JP (2011) Sex differences in synaptic plasticity in stress-responsive brain regions following chronic variable stress. Physiol Behav 104:242-247. CrossRef Medline

Chow C, Epp JR, Lieblich SE, Barha CK, Galea LA (2013) Sex differences in neurogenesis and activation of new neurons in response to spatial learning and memory. Psychoneuroendocrinology 38:1236-1250. CrossRef Medline

Dalla C, Edgecomb C, Whetstone AS, Shors TJ (2008) Females do not express learned helplessness like males do. Neuropsychopharmacology 33: 1559-1569. CrossRef Medline

Dalla C, Pitychoutis PM, Kokras N, Papadopoulou-Daifoti Z (2011) Sex differences in response to stress and expression of depressive-like behaviours in the rat. Curr Top Behav Neurosci 8:97-118. CrossRef Medline

Dodge JE, Okano M, Dick F, Tsujimoto N, Chen T, Wang S, Ueda Y, Dyson N, Li E (2005) Inactivation of Dnmt3b in mouse embryonic fibroblasts results in DNA hypomethylation, chromosomal instability, and spontaneous immortalization. J Biol Chem 280:17986-17991. CrossRef Medline

Elliott E, Ezra-Nevo G, Regev L, Neufeld-Cohen A, Chen A (2010) Resilience to social stress coincides with functional DNA methylation of the Crf gene in adult mice. Nat Neurosci 13:1351-1353. CrossRef Medline

Farrell MR, Gruene TM, Shansky RM (2015) The influence of stress and gonadal hormones on neuronal structure and function. Horm Behav 2015:piiS0018-506X(15)00036-7. CrossRef Medline

Feng J, Zhou Y, Campbell SL, Le T, Li E, Sweatt JD, Silva AJ, Fan G (2010) Dnmt1 and Dnmt3a maintain DNA methylation and regulate synaptic function in adult forebrain neurons. Nat Neurosci 13:423-430. CrossRef Medline

Feng J, Wilkinson M, Liu X, Purushothaman I, Ferguson D, Vialou V, Maze I, Shao N, Kennedy P, Koo J, Dias C, Laitman B, Stockman V, LaPlant Q, Cahill ME, Nestler EJ, Shen L (2014) Chronic cocaine-regulated epigenomic changes in mouse nucleus accumbens. Genome Biol 15:R65. CrossRef Medline

File SE (2001) Factors controlling measures of anxiety and responses to novelty in the mouse. Behav Brain Res 125:151-157. CrossRef Medline 
Galea LA, Wainwright SR, Roes MM, Duarte-Guterman P, Chow C, Hamson DK (2013) Sex, hormones and neurogenesis in the hippocampus: hormonal modulation of neurogenesis and potential functional implications. J Neuroendocrinol 25:1039-1061. CrossRef Medline

Ghahramani NM, Ngun TC, Chen PY, Tian Y, Krishnan S, Muir S, Rubbi L, Arnold AP, de Vries GJ, Forger NG, Pellegrini M, Vilain E (2014) The effects of perinatal testosterone exposure on the DNA methylome of the mouse brain are late-emerging. Biol Sex Differ 5:8. CrossRef Medline

Golde WT, Gollobin P, Rodriguez LL (2005) A rapid, simple, and humane method for submandibular bleeding of mice using a lancet. Lab Anim (NY) 34:39-43. CrossRef Medline

Golden SA, Christoffel DJ, Heshmati M, Hodes GE, Magida J, Davis K, Cahill ME, Dias C, Ribeiro E, Ables JL, Kennedy PJ, Robison AJ, GonzalezMaeso J, Neve RL, Turecki G, Ghose S, Tamminga CA, Russo SJ (2013) Epigenetic regulation of RAC1 induces synaptic remodeling in stress disorders and depression. Nat Med 19:337-344. CrossRef Medline

Hervouet E, Vallette FM, Cartron PF (2009) Dnmt3/transcription factor interactions as crucial players in targeted DNA methylation. Epigenetics 4:487-499. CrossRef Medline

Hodes GE, Yang L, Van Kooy J, Santollo J, Shors TJ (2009) Prozac during puberty: distinctive effects on neurogenesis as a function of age and sex. Neuroscience 163:609-617. CrossRef Medline

Hodes GE, Hill-Smith TE, Suckow RF, Cooper TB, Lucki I (2010) Sexspecific effects of chronic fluoxetine treatment on neuroplasticity and pharmacokinetics in mice. J Pharmacol Exp Ther 332:266-273. CrossRef Medline

Hodes GE, Pfau ML, Leboeuf M, Golden SA, Christoffel DJ, Bregman D, Rebusi N, Heshmati M, Aleyasin H, Warren BL, Lebonté B, Horn S, Lapidus KA, Stelzhammer V, Wong EH, Bahn S, Krishnan V, BolañosGuzman CA, Murrough JW, Merad M, et al. (2014) Individual differences in the peripheral immune system promote resilience versus susceptibility to social stress. Proc Natl Acad Sci U S A 111:16136-16141. CrossRef Medline

Howerton AR, Roland AV, Fluharty JM, Marshall A, Chen A, Daniels D, Beck SG, Bale TL (2014) Sex differences in corticotropin-releasing factor receptor-1 action within the dorsal raphe nucleus in stress responsivity. Biol Psychiatry 75:873-883. CrossRef Medline

Isingrini E, Camus V, Le Guisquet AM, Pingaud M, Devers S, Belzung C (2010) Association between repeated unpredictable chronic mild stress (UCMS) procedures with a high fat diet: a model of fluoxetine resistance in mice. PLoS One 5:e10404. CrossRef Medline

Jensen Peña C, Monk C, Champagne FA (2012) Epigenetic effects of prenatal stress on 11beta-hydroxysteroid dehydrogenase-2 in the placenta and fetal brain. PLoS One 7:e39791. CrossRef Medline

Kelly SD, Harrell CS, Neigh GN (2014) Chronic stress modulates regional cerebral glucose transporter expression in an age-specific and sexuallydimorphic manner. Physiol Behav 126:39-49. CrossRef Medline

Kessler RC (2003) Epidemiology of women and depression. J Affect Disord 74:5-13. CrossRef Medline

Kessler RC, McGonagle KA, Zhao S, Nelson CB, Hughes M, Eshleman S, Wittchen HU, Kendler KS (1994) Lifetime and 12-month prevalence of DSM-III-R psychiatric disorders in the United States. Results from the National Comorbidity Survey. Arch Gen Psychiatry 51:8-19. CrossRef Medline

Kim DR, Bale TL, Epperson CN (2015) Prenatal programming of mental illness: current understanding of relationship and mechanisms. Curr Psychiatry Rep 17:5. CrossRef Medline

Kim D, Pertea G, Trapnell C, Pimentel H, Kelley R, Salzberg SL (2013) TopHat2: accurate alignment of transcriptomes in the presence of insertions, deletions and gene fusions. Genome Biol 14:R36. CrossRef Medline

Krishnan V, Han MH, Graham DL, Berton O, Renthal W, Russo SJ, Laplant Q, Graham A, Lutter M, Lagace DC, Ghose S, Reister R, Tannous P, Green TA, Neve RL, Chakravarty S, Kumar A, Eisch AJ, Self DW, Lee FS, et al. (2007) Molecular adaptations underlying susceptibility and resistance to social defeat in brain reward regions. Cell 131:391-404. CrossRef Medline

Kurian JR, Olesen KM, Auger AP (2010) Sex differences in epigenetic regulation of the estrogen receptor-alpha promoter within the developing preoptic area. Endocrinology 151:2297-2305. CrossRef Medline

LaPlant Q, Chakravarty S, Vialou V, Mukherjee S, Koo JW, Kalahasti G, Bradbury KR, Taylor SV, Maze I, Kumar A, Graham A, Birnbaum SG, Krishnan V, Truong HT, Neve RL, Nestler EJ, Russo SJ (2009) Role of nuclear factor kappaB in ovarian hormone-mediated stress hypersensitivity in female mice. Biol Psychiatry 65:874-880. CrossRef Medline

LaPlant Q, Vialou V, Covington HE 3rd, Dumitriu D, Feng J, Warren BL, Maze I, Dietz DM, Watts EL, Iñiguez SD, Koo JW, Mouzon E, Renthal W, Hollis F, Wang H, Noonan MA, Ren Y, Eisch AJ, Bolaños CA, Kabbaj M, et al. (2010) Dnmt3a regulates emotional behavior and spine plasticity in the nucleus accumbens. Nat Neurosci 13:1137-1143. CrossRef Medline

Law CW, Chen Y, Shi W, Smyth GK (2014) voom: precision weights unlock linear model analysis tools for RNA-seq read counts. Genome Biol 15: R29. CrossRef Medline

Lynch WJ, Carroll ME (2000) Reinstatement of cocaine self-administration in rats: sex differences. Psychopharmacology (Berl) 148: 196-200. CrossRef Medline

Lynch WJ, Arizzi MN, Carroll ME (2000) Effects of sex and the estrous cycle on regulation of intravenously self-administered cocaine in rats. Psychopharmacology (Berl) 152:132-139. CrossRef Medline

MacLean HE, Warne GL, Zajac JD (1997) Intersex disorders: shedding light on male sexual differentiation beyond SRY. Clin Endocrinol (Oxf) 46: 101-108. CrossRef Medline

Martin LA, Neighbors HW, Griffith DM (2013) The experience of symptoms of depression in men vs women: analysis of the National Comorbidity Survey Replication. JAMA Psychiatry 70:1100-1106. CrossRef Medline

Matsuda KI, Mori H, Nugent BM, Pfaff DW, McCarthy MM, Kawata M (2011) Histone deacetylation during brain development is essential for permanent masculinization of sexual behavior. Endocrinology 152:2760 2767. CrossRef Medline

McCarthy MM, Auger AP, Bale TL, De Vries GJ, Dunn GA, Forger NG, Murray EK, Nugent BM, Schwarz JM, Wilson ME (2009) The epigenetics of sex differences in the brain. J Neurosci 29:12815-12823. CrossRef Medline

McEwen BS, Gray J, Nasca C (2015) Recognizing resilience: learning from the effects of stress on the brain. Neurobiol Stress 1:1-11. CrossRef Medline

Monteggia LM, Luikart B, Barrot M, Theobold D, Malkovska I, Nef S, Parada LF, Nestler EJ (2007) Brain-derived neurotrophic factor conditional knockouts show gender differences in depression-related behaviors. Biol Psychiatry 61:187-197. CrossRef Medline

Morrison KE, Rodgers AB, Morgan CP, Bale TL (2014) Epigenetic mechanisms in pubertal brain maturation. Neuroscience 264:17-24. CrossRef Medline

Murray EK, Hien A, de Vries GJ, Forger NG (2009) Epigenetic control of sexual differentiation of the bed nucleus of the stria terminalis. Endocrinology 150:4241-4247. CrossRef Medline

Nugent BM, Wright CL, Shetty AC, Hodes GE, Lenz KM, Mahurkar A, Russo SJ, Devine SE, McCarthy MM (2015) Brain feminization requires active repression of masculinization via DNA methylation. Nat Neurosci 18 : 690-697. CrossRef Medline

Pishva E, Drukker M, Viechtbauer W, Decoster J, Collip D, van Winkel R, Wichers M, Jacobs N, Thiery E, Derom C, Geschwind N, van den Hove D, Lataster T, Myin-Germeys I, van Os J, Rutten BP, Kenis G (2014) Epigenetic genes and emotional reactivity to daily life events: a multi-step gene-environment interaction study. PLoS One 9:e100935. CrossRef Medline

Rappeneau V, Morel AL, El Yacoubi M, Vaugeois JM, Denoroy L, Berod A (2015) Enhanced cocaine-associated contextual learning in female H/Rouen mice selectively bred for depressive-like behaviors: molecular and neuronal correlates. Int J Neuropsychopharmacol 18:piipyv022. CrossRef Medline

Rhees RW, Shryne JE, Gorski RA (1990) Onset of the hormone-sensitive perinatal period for sexual differentiation of the sexually dimorphic nucleus of the preoptic area in female rats. J Neurobiol 21:781-786. CrossRef Medline

Ritchie ME, Phipson B, Wu D, Hu Y, Law CW, Shi W, Smyth GK (2015) limma powers differential expression analyses for RNA-sequencing and microarray studies. Nucleic Acids Res 43:e47. CrossRef Medline

Robertson KD, Wolffe AP (2000) DNA methylation in health and disease. Nat Rev Genet 1:11-19. CrossRef Medline

Russo SJ, Nestler EJ (2013) The brain reward circuitry in mood disorders. Nat Rev Neurosci 14:609-625. CrossRef Medline

Russo SJ, Jenab S, Fabian SJ, Festa ED, Kemen LM, Quinones-Jenab V (2003) 
Sex differences in the conditioned rewarding effects of cocaine. Brain Res 970:214-220. CrossRef Medline

Santarelli L, Saxe M, Gross C, Surget A, Battaglia F, Dulawa S, Weisstaub N, Lee J, Duman R, Arancio O, Belzung C, Hen R (2003) Requirement of hippocampal neurogenesis for the behavioral effects of antidepressants. Science 301:805-809. CrossRef Medline

Sato SM, Wissman AM, McCollum AF, Woolley CS (2011) Quantitative mapping of cocaine-induced DeltaFosB expression in the striatum of male and female rats. PLoS One 6:e21783. CrossRef Medline

Schübeler D (2015) Function and information content of DNA methylation. Nature 517:321-326. CrossRef Medline

Schwarz JM, Nugent BM, McCarthy MM (2010) Developmental and hormone-induced epigenetic changes to estrogen and progesterone receptor genes in brain are dynamic across the life span. Endocrinology 151:4871-4881. CrossRef Medline

Shansky RM, Hamo C, Hof PR, Lou W, McEwen BS, Morrison JH (2010) Estrogen promotes stress sensitivity in a prefrontal cortex-amygdala pathway. Cereb Cortex 20:2560-2567. CrossRef Medline

Shen EY, Ahern TH, Cheung I, Straubhaar J, Dincer A, Houston I, de Vries GJ, Akbarian S, Forger NG (2015) Epigenetics and sex differences in the brain: a genome-wide comparison of histone- 3 lysine- 4 trimethylation (H3K4me3) in male and female mice. Exp Neurol 268:21-29. CrossRef Medline

Shors TJ, Falduto J, Leuner B (2004) The opposite effects of stress on dendritic spines in male vs. female rats are NMDA receptor-dependent. Eur J Neurosci 19:145-150. CrossRef Medline

Solomon MB, Karom MC, Huhman KL (2007) Sex and estrous cycle differences in the display of conditioned defeat in Syrian hamsters. Horm Behav 52:211-219. CrossRef Medline

Spiegel I, Mardinly AR, Gabel HW, Bazinet JE, Couch CH, Tzeng CP, Harmin DA, Greenberg ME (2014) Npas4 regulates excitatory-inhibitory balance within neural circuits through cell-type-specific gene programs. Cell 157:1216-1229. CrossRef Medline

Stevens JS, Almli LM, Fani N, Gutman DA, Bradley B, Norrholm SD, Reiser E, Ely TD, Dhanani R, Glover EM, Jovanovic T, Ressler KJ (2014) PACAP receptor gene polymorphism impacts fear responses in the amygdala and hippocampus. Proc Natl Acad Sci U S A 111:3158-3163. CrossRef Medline

Surget A, Saxe M, Leman S, Ibarguen-Vargas Y, Chalon S, Griebel G, Hen R, Belzung C (2008) Drug-dependent requirement of hippocampal neurogenesis in a model of depression and of antidepressant reversal. Biol Psychiatry 64:293-301. CrossRef Medline

Trainor BC, Pride MC, Villalon Landeros R, Knoblauch NW, Takahashi EY, Silva AL, Crean KK (2011) Sex differences in social interaction behavior following social defeat stress in the monogamous California mouse (Peromyscus californicus). PLoS One 6:e17405. CrossRef Medline

Tsai HW, Grant PA, Rissman EF (2009) Sex differences in histone modifications in the neonatal mouse brain. Epigenetics 4:47-53. CrossRef Medline

Tsankova NM, Berton O, Renthal W, Kumar A, Neve RL, Nestler EJ (2006) Sustained hippocampal chromatin regulation in a mouse model of depression and antidepressant action. Nat Neurosci 9:519-525. CrossRef Medline

Ver Hoeve ES, Kelly G, Luz S, Ghanshani S, Bhatnagar S (2013) Short-term and long-term effects of repeated social defeat during adolescence or adulthood in female rats. Neuroscience 249:63-73. CrossRef Medline

Vialou V, Maze I, Renthal W, LaPlant QC, Watts EL, Mouzon E, Ghose S, Tamminga CA, Nestler EJ (2010) Serum response factor promotes resilience to chronic social stress through the induction of DeltaFosB. J Neurosci 30:14585-14592. CrossRef Medline

Wang X, Meng FS, Liu ZY, Fan JM, Hao K, Chen XQ, Du JZ (2013) Gestational hypoxia induces sex-differential methylation of Crhrl linked to anxiety-like behavior. Mol Neurobiol 48:544-555. CrossRef Medline

Wissman AM, McCollum AF, Huang GZ, Nikrodhanond AA, Woolley CS (2011) Sex differences and effects of cocaine on excitatory synapses in the nucleus accumbens. Neuropharmacology 61:217-227. CrossRef Medline

Wissman AM, May RM, Woolley CS (2012) Ultrastructural analysis of sex differences in nucleus accumbens synaptic connectivity. Brain Struct Funct 217:181-190. CrossRef Medline

Yoganathan N, Yee A, Zhang Z, Leung D, Yan J, Fazli L, Kojic DL, Costello PC, Jabali M, Dedhar S, Sanghera J (2002) Integrin-linked kinase, a promising cancer therapeutic target: biochemical and biological properties. Pharmacol Ther 93:233-242. CrossRef Medline 